\title{
Do Personal Taxes affect Corporate Financing Decisions?
}

John R. Graham*

November 25, 1998

The traditional view is that interest deductibility encourages firms to use debt financing; however, some argue that the personal tax disadvantage to interest offsets the corporate tax advantage. This paper investigates the degree to which personal taxes affect corporate financing decisions. In crosssectional regressions that control for personal taxes, debt usage is positively correlated with tax rates in each year 1980-1994, with significant coefficients in almost every year. A specification that adjusts tax benefits for the personal tax penalty statistically dominates a specification that does not. The positive (negative) effect of corporate (personal) taxes on debt usage is distinctly identified.

Keywords: debt, corporate taxes, personal taxes, capital structure, taxes

JEL classification: G32, H20

*Correspondence: email: john.graham@duke.edu. Postal: Fuqua School of Business, Duke University, Durham NC, 27708-0120. Phone: (919) 660-7857. Fax: (919) 684-2818. 


\section{Introduction}

The trade-off theory of financing choice argues that firms choose unique optimal capital structures by balancing the benefits of debt finance with expected costs of financial distress [e.g., Scott (1976), Bradley, Jarrell, and Kim (1984)]. A long-held belief is that the tax deductibility of interest payments provides one of the primary benefits of debt issuance, implying that debt usage should increase with tax rates. Although it took some time to find empirical evidence consistent with this belief [Myers' (1984) "capital structure puzzle"], recent research shows that taxes affect financing decisions in the manner predicted by the trade-off theory.

MacKie-Mason (1990), Trezevant (1992), Graham (1996a), and Shum (1996) document that incremental financing choices involve relatively little debt for firms with effectively low corporate tax rates. Gordon and MacKie-Mason (1990), Givoly, Hahn, Ofer, and Sarig (1992), and Rajan and Zingales (1995) find that, following changes in tax rates that make debt more attractive, firms incrementally increase the portion of capital structure comprised by debt. Graham, Lemmon, and Schallheim (1998) use before-financing tax rates to document that firms with high tax rates have relatively high levels of debt. Schulman et al. (1996) find that debt levels are positively correlated to tax rates in Canada and New Zealand, while Desai (1997) finds a positive cross-sectional correlation between debt usage and taxes across a sample of 51 countries. Dhaliwal, Trezevant, and Wang (1992) find a positive relation between taxes and both debt levels and tax shielding ratios.

Implicit in all these papers is the notion that a principal benefit of debt finance is the interest deduction, perhaps net of the personal tax disadvantage. However, (with the exception of Gordon and MacKie-Mason and Desai) these capital structure papers do not emphasize the personal tax 
disadvantage to debt financing. ${ }^{1}$ Investigating whether personal taxes affect corporate financing decisions is important because some researchers [e.g., Miller (1977)] argue that, at the margin, the personal tax penalty completely negates the corporate tax advantage to debt; this implies that taxinduced, firm-specific optimal capital structures should not exist in equilibrium.

This paper focuses on the measurement and importance of personal taxes in the context of corporate financial decision-making. If investors are taxed heavily on interest income (relative to taxation on equity income), they demand higher risk-adjusted returns for holding debt (relative to holding equity), thereby discouraging the use of debt at the corporate level. The personal tax burden on interest income is generally higher than that for equity income because 1) long-term capital gains are often taxed at a rate below statutory personal rates, 2) taxes on capital gains can be deferred until the gain is realized, and 3) capital gains taxes can be avoided altogether if equity shares are held until death. This paper investigates whether the intensity of corporate debt financing varies with the personal tax burden and whether the personal tax penalty is better measured as a single value across all firms in a given year, or allowed to vary across firms depending on their dividend policy. The paper's primary contributions are the documentation that personal taxes provide a disincentive to use of debt, the relatively precise measurement of corporate tax effects, and the variety of specifications that document tax effects that are consistent with firm-specific optimal capital structure. This last finding indicates that personal taxes do not completely negate the corporate tax advantage to debt.

When the personal tax penalty is measured on a firm-specific basis, there is strong evidence that the firms that reap the largest benefit from interest deductions use the most debt. This finding is robust to a number of different specifications:

${ }^{1}$ Gordon and MacKie-Mason $(1994,1997)$ explore how personal taxes affect the costs and benefits of incorporation and the decision about whether or not to incorporate. 
- $\quad$ Pooled cross-sectional time-series analysis of debt levels, and separately, for changes in debt;

- $\quad$ Annual debt-level (and separately, debt-changes) regressions for each year, 1980-1994;

- Regressions in which marginal tax rates are simulated in a manner that accounts for carrybacks, carryforwards, and other major features of the tax code, and also with "average marginal" tax rates calculated by Poterba (1997);

- $\quad$ Subsets of firms with and without credit ratings.

Further analysis distinguishes a separate positive effect of corporate taxes from the negative effect of personal taxes on debt usage. A non-nested regression test indicates that a firm-specific personal tax adjustment statistically dominates a specification that ignores personal taxes.

When the personal tax penalty is measured as a single value across all firms in any given year, the results are weaker: positive and significant tax effects in only 11 of 15 years. Thus, it is advantageous to use firm-specific information when adjusting for personal taxes. This result can be interpreted as implying that firms have tax clienteles (in contrast to the idea that there is one marginal investor between debt and equity for the entire economy) similar to the dividend clientele results of Elton and Gruber (1970), Auerbach (1983), and Sholz (1992).

In addition to being statistically significant, the results are economically important. Using mean 1994 data for the non-tax variables, but allowing the tax rates to equal their largest 1994 values ((0.277 federal (net of personal taxes), 0.099 state), the hypothetical "highest tax rate firm" debt-tovalue ratio is $24.1 \%$. When the tax rates are equal to their smallest 1994 values, the "lowest tax rate" debt ratio is $18.1 \%$. Thus, the estimated tax coefficient implies that high tax rate firms will, on average, have debt-to-value ratios that are approximately 600 basis points higher than debt ratios for low tax rate firms. The effect of the personal tax penalty is less important economically: if there were no personal tax penalty, the "high tax rate" debt ratio would be $24.9 \%$. The results also imply that the 1997 tax legislation (reducing the capital gains tax rate on equity, thereby increasing the personal tax penalty associated with debt) will result in a very small reduction in debt financing. 
The rest of the paper proceeds as follows. Section 2 discusses issues related to measuring debt policy in level- and difference-form. Section 3 describes how the marginal tax rates are estimated and how personal and state taxes are factored in. Section 4 describes the data sources and defines the variables used in the analysis. Section 5 performs capital structure regressions, and Section 6 concludes.

\section{Debt levels or changes in debt?}

In an influential paper, MacKie-Mason (1990) examines 1,747 debt and equity issues from 1977-1987 and finds that firms with effectively high tax rates are more likely to issue debt than are firms with low tax rates. MacKie-Mason argues that studying incremental financing choice is advantageous relative to examining debt levels (such as debt ratios), because the latter reflect the cumulation of many historical decisions, which may obscure whether taxes influence current-period financing choice. The incremental approach only requires that firms make the appropriate debt-equity choice at the time of security issuance, given their current position, and not necessarily that firms rebalance to their optimal debt-equity ratio with each issuance (as is sometimes implicit debt level studies). MacKie-Mason uses the lagged value of the tax rate when explaining current-period financing choice, implying that firms with high tax rates are relatively likely to use debt at the time of their next security issuance; I also use lagged tax rates in the incremental analysis in Section 5.6.

MacKie-Mason's sample consists of firms that issue securities; in particular, a "0" indicates equity issuance and a " 1 " indicates debt issuance. But what happens when a researcher is uses data that are not conditional on security issuance? For example, the standard Compustat data used in many studies are simply the concatenation of twenty years worth of annual reports, regardless of whether a firm visits the security markets. With this type of data, and given positive transactions 
costs, the measured change in long-term debt can easily be " 0 " in many years (or if the debt is paid down according to a sinking fund schedule, the change in debt can be a relatively small negative amount in many years). If a firm with a high tax rate does not issue any debt, does this " 0 " indicate that the firm does not respond to the incentive of interest tax deductions, or simply that the firm is not currently in need of external funds? While (lack of) incremental financing choices are sometimes hard to interpret with this type of data, if one were able to address the "cumulative effects of historical decisions" problem identified by MacKie-Mason, one should find that high-tax rate firms have plentiful debt throughout the sample, even if they do not often issue new securities.

Graham, Lemmon, and Schallheim (1998) show that the "cumulative effect" of past financing decisions on tax rates can be removed by using a before-financing tax variable (that is, based on income before interest is deducted). In particular, they show that there is a spurious negative relation between debt ratios and tax rates when taxes are measured with after-financing income (because firms with substantial debt have lots of interest deductions, pushing down their taxable income and reducing their expected marginal tax rate), while debt ratios and before-financing tax rates are positively correlated, as implied by theory. Thus, given a properly constructed tax variable, it is possible to document tax effects using debt levels, even for a sample of firms that are not necessarily issuing new securities. (Note that other possible problems from "cumulative effects", perhaps resulting from past investment decisions or path-specific hysteresis, are not avoided by using before-financing tax rates; the Graham, Lemmon, and Schallheim results suggest that these problems are not sufficient to overwhelm tax effects.) I adopt the convention of using before-financing tax rates in my debt-level analysis (in contrast to the changes-in-debt analysis, which uses tax rates based on after-financing income, as mentioned in the first paragraph of this section). 


\section{Estimating marginal tax rates}

\section{A. Simulating corporate marginal income tax rates}

Recent research indicates that when estimating a firm's tax rate, it is important to consider the effect of net operating losses (NOL), the investment tax credit (ITC), the alternative minimum tax (AMT), the progressivity of the statutory tax code, and uncertainty about future taxable income [see Shevlin (1987), MacKie-Mason (1990), and Graham, (1996a, 1996b)]. For example, consider a firm that pays taxes today at the top federal rate of $35 \%$. Assume that the firm 1) had zero taxable income in each of the past three years, 2) earns $\$ 1$ million today, 3) expects to earn either $\$ 1.1$ million (0.50 probability) or lose $\$ 1.1$ million ( 0.50 probability) next year, and 4$)$ knows with certainty that it will make $\$ 2$ million every year from $t+2$ onward. If the "bad outcome" occurs, this firm will "carry back" $\$ 1$ million of the $t+1$ loss to obtain a refund on taxes paid in $t$, and have $\$ 100,000$ left to "carry forward" to shield taxable income in $t+2$.

The firm's marginal tax rate is calculated by determining the present value of taxes owed on an extra dollar of income earned today. The firm pays tax of $\$ 0.35$ on a extra dollar today. If the bad outcome occurs next year, the $\$ 0.35$ tax on the extra dollar will be refunded in $t+1$; however, this will leave the firm with $\$ 1$ less to carryforward to shield income in $t+2$. Abstracting from other features of the tax code, earning an extra dollar today has an incremental tax effect of $\$ 0.35,-\$ 0.35$, $\$ 0.35$ on the firm's tax liability in years $t, t+1$, and $t+2$, respectively. If the good outcome occurs next year, the firm will pay taxes of $\$ 0.35$ on an extra dollar today, with no ensuing carryforwards or carrybacks in $t+1$ and beyond. Assuming that the firm has a $10 \%$ discount rate, it has an expected marginal tax rate of $33.6 \%$ today $\left(0.336=0.35-1 / 2\left(\frac{0.35}{1.1}\right)+1 / 2\left(\frac{0.35}{1.1^{2}}\right)\right)$. Alternatively, a firm that carries forward a large NOL into the present period may not expect to pay current taxes, and hence 
have a low effective marginal tax rate. ${ }^{2}$ These examples imply that it is desirable to consider both past and forecasted income when determining current corporate tax status.

To account for the dynamic nature of the tax code (e.g., 3-year carryback and 15-year carryforward periods for both NOLs and ITC) ${ }^{3}$, I follow the procedure outlined in Graham (1996a, 1996b) to simulate tax rates. ${ }^{4}$ To estimate a tax rate for firm $i$ in year $t$, the firm's taxable income from year $t-3$ to $t+18$ is considered. ${ }^{5}$ To forecast taxable income, I use Graham's (1996b) main model which states that firm $i$ 's taxable income follows a pseudo-random walk with drift:

$$
\Delta T I_{i t}=\mu_{i}+\epsilon_{i t}
$$

where $\Delta \mathrm{TI}_{\mathrm{it}}$ is the first difference in taxable income, $\mu_{\mathrm{i}}$ is the maximum of the mean of $\Delta \mathrm{TI}_{\mathrm{i}}$ and zero, and $\epsilon_{\mathrm{it}}$ is distributed normally with mean zero and variance equal to that of $\Delta \mathrm{TI}_{\mathrm{i}}$. (Graham (1996b) shows that the "pseudo" random walk, where the drift is constrained to be nonnegative, predicts the true marginal tax rate better than a model that does not constrain the drift term.) The means and variances are estimated on a "rolling historical" basis; that is, they are based on data up to year $t-1$ for each year- $t$ calculation. Taxable income is estimated from the Compustat tapes using earnings

\footnotetext{
${ }^{2}$ The examples rely on the tax-loss carryback and carryforward provisions of the federal income tax code. The marginal tax rate can also be affected by tax rules allowing firms to carry alternative minimum tax credits forward indefinitely, or carry investment tax credits back three years and forward up to 15 years [see Graham (1996b)]. This last feature indicates that the ITC may affect some firm's tax rates through the year 2000 even though the Tax Reform Act of 1986 eliminated the possibility of accumulating any new ITC.

${ }^{3}$ Starting with tax years ending after August 5, 1997, the tax-loss carryback period is two years and the carryforward period is twenty years. See Graham and Lemmon (1998) for updated tax rules.

${ }^{4}$ Shevlin $(1987,1990)$ used a similar technique to simulate tax rates. Auerbach and Poterba (1987) and Altshuler and Auerbach (1990) simulate tax rates using first-order Markov transition probabilities.

${ }^{5}$ The tax consequences of income earned today may not be realized for 15 years if a firm is not expected to have positive net taxable income (TI) for the next 14 years. Furthermore, $\mathrm{TI}_{\mathrm{t}+15}$ can be affected by $\mathrm{TI}_{\mathrm{t}+18}$ due to carryback rules; therefore, 18 years of future income are forecasted to calculate current-period marginal tax rates.
} 
minus deferred tax expense, with the latter term divided by the appropriate statutory corporate tax rate so that it is expressed on a pre-tax basis. (As discussed in Section 2, in the debt level analysis, income is defined as earnings before interest and taxes (EBIT); in the incremental analysis, income is defined as earnings before taxes but after interest deductions.) Income is also adjusted for discontinued and extraordinary items, with these terms grossed up by one minus the appropriate statutory tax rate so they are expressed on a pre-tax basis, although these items are not included in the calculation of the means and variances.

When estimating $\mathrm{MTR}_{\mathrm{it}}$ a forecast of firm $i$ 's taxable income for the years $t+1$ through $t+18$ is obtained by drawing 18 random normal realizations of $\epsilon_{\mathrm{it}}$ and using equation (1). Next, the present value of the tax bill from $t-3$ (to account for carrybacks) through $t+18$ (to account for carryforwards) is calculated. Taxes paid in the years $t+1$ through $t+18$ are discounted using the average corporate bond yield, as gathered from Moody's Bond Record; taxes for the years $t$ - 3 through $t$ - 1 are not discounted or grossed-up because, for all practical purposes, tax refunds are not paid with interest. The tax bill is calculated using the entire corporate tax schedule, and not just the top statutory rate, as gathered from Commerce Clearing House publications. Next, $\$ 10,000$ is added to taxable income in year $t$ and the present value of the tax bill is recalculated. The difference between the two tax bills (divided by $\$ 10,000$ ) represents the present value of taxes owed on an extra dollar of income earned by firm $i$ in year $t$ (i.e., a single simulated estimate of $\mathrm{MTR}_{\mathrm{it}}$ ).

The simulation procedure just described is repeated 50 times to obtain 50 estimates of MTR $_{\mathrm{i}}$ in year $t$; each simulation is based on a new forecast of 18 years of taxable income. (Graham (1996b) shows that tax rates based on 50 simulations per firm-year predict the true marginal tax rate as well as tax rates based on 1000 simulations per firm-year.) The mean of the 50 estimates of the marginal tax rate is the expected $\mathrm{MTR}_{\mathrm{it}}$ for firm $i$ in year $t$, a single expected $\mathrm{MTR}_{\mathrm{it}}$ for a single firm-year. This 
technique is repeated for each company in the sample, for each year between 1980 and 1994.

\section{B. The effect of personal and state taxes}

Corporate marginal tax rates provide an estimate of the reduction in tax liability that results from deducting a dollar of interest. However, the tax rates potentially overstate the benefit to the firm because, at the personal level, interest income is taxed at a rate that is generally higher than the tax rate on returns from common stock. Therefore, there is a "personal tax penalty" associated with interest deductions [Farrar and Selwyn (1967), Miller (1977)] because investors demand a higher risk-adjusted pre-tax return for debt investments relative to equity investments. To measure the firm's net benefit from interest deductions, the marginal tax rates must be adjusted to account for the personal tax penalty. The net tax advantage to debt (relative to equity) can be represented as the proceeds received by investors from a dollar of interest income less those from a dollar of equity:

$$
\left(1-\tau_{p}\right)-\left(1-\tau_{c}\right)\left(1-\tau_{e}\right)
$$

which can be rewritten as

$$
\tau_{c}-\left[\tau_{p}-\left(1-\tau_{c}\right) \tau_{e}\right]
$$

where $\tau_{c}$ is the corporate income tax rate, $\tau_{\mathrm{e}}$ is the personal tax rate on equity income, and $\tau_{\mathrm{p}}$ is the personal tax rate on interest income. The second and third terms in equation (3) account for the personal tax penalty: $\tau_{\mathrm{p}}-\left(1-\tau_{\mathrm{c}}\right) \tau_{\mathrm{e}}$. I follow Gordon and MacKie-Mason (1990) and estimate $\tau_{\mathrm{e}}$ as $[d$ $+(1-d) g \alpha] \tau_{\mathrm{p}}$, where $d$ is the dividend-payout ratio, $g$ is the proportion of long-term gains that are taxable, $\alpha$ measures the benefits from deferring taxes on capital gains, and dividends are taxed at the 
same rate as interest income $\left(\tau_{\mathrm{p}}\right)^{6,7}$

There are at least two ways to empirically measure the theoretical relation in equation (3): i) assume that the arbitrage relation between debt and equity returns is driven by a single "marginal investor," and therefore use economy-wide information [for related research, see, e.g., Gordon and Bradford (1980), Gordon (1982), Gordon and MacKie-Mason (1990), and Scholes and Wolfson (1992)], or ii) assume that certain firm-specific characteristics can affect equation (3), perhaps because of tax clienteles, and therefore use firm-specific information [e.g., Elton and Gruber (1970), Auerbach (1983), and Sholz (1992) find evidence of tax clienteles among investors based on a firm's dividend policy; see also Zechner (1990), Givoly, Hahn, Ofer, and Sarig (1992), and Green and Rydqvist (1999)]. ${ }^{8,9}$ In Section 5, results using both methods are contrasted to determine which is more informative.

An effort is also made to account for the effect of state taxes on the benefits of debt financing.

${ }^{6}$ The "traditional view" is that equity returns are taxed when the equity is returned to shareholders in the form of dividends, and so it is appropriate that dividend taxes be included in the $\tau_{\mathrm{e}}$ term in equations (2) and (3). In contrast, the "tax capitalization" view argues that future dividend taxes are already capitalized into the price of retained earnings, and so it is not appropriate to factor in the effect of dividend taxation when evaluating the cost of projects financed with retained earnings. (Both views agree that dividend taxation should be considered when evaluating the cost of new equity.) The jury is out as to which of these views is correct [see Zodrow (1991)]. The analysis in the present paper is most consistent with the "traditional view."

${ }^{7}$ In a companion paper, Graham (1999) uses this modeling approach to estimate the value of interest deductibility by firm and across the economy. The capitalized tax benefits of debt equal between $5 \%$ and $10 \%$ of firm value.

${ }^{8}$ In addition to the possibility of tax clienteles, firm-specific information may be helpful in the context of adjusting for risk. The relation in equation (3) measures the tax advantage of debt based on risk-adjusted bond and equity returns [Scholes and Wolfson (1992)]. Of course, determining an appropriate risk adjustment is one of the more contentious issues in financial economics. Therefore, in practice the risk-adjustment is often not explicitly performed [e.g., see Gordon and MacKie-Mason (1990), Rajan and Zingales (1995), Graham (1996a)]. If the debt and equity for a firm are in the same general risk class (e.g., firms that issue junk bonds also have relatively risky equity), then using firm-specific information to estimate equation (3) represents a first step towards holding risk constant when determining the net tax advantage to debt.

${ }^{9}$ Not all research finds evidence of tax clienteles [e.g., see Lewellen, Stanley, Lease, and Schlarbaum (1978) and Michaely (1991)]. See Bali and Hite (1998) and Frank and Jagannathan (1998) for marketmicrostructure explanations of the ex-dividend behavior of stock prices. 
Tax schedules from all 50 states are used to calculate the statutory marginal tax rate, based on beforefinancing income, to measure state taxes (Source: Fiscal Federalism). While it would be ideal to simulate state tax rates, it is well beyond the scope of this paper to gather information on statespecific tax laws. In an attempt to capture some of the effects that uncertainty and the dynamic nature of the tax code may have on the effective state tax rate, the statutory state rate is multiplied by the ratio of the simulated federal rate over the statutory federal rate. For example, if the statutory state rate is $10 \%$ and the statutory federal rate is $35 \%$, but the effective federal rate is $33.6 \%$ (as in

the example at the start of Section 3A), the state rate is computed as $9.6 \%\left(0.096=0.10\left(\frac{0.336}{0.35}\right)\right)$. Finally, given that state taxes are deductible at the federal level, effective state taxes are measured as $\left(1-\tau_{\text {Federal }}\right) \tau_{\text {State }}$

An important issue related to the use of state tax rates is that firms pay taxes on the net revenues they earn in each state of operation, while Compustat only provides information about a company's "principal location." The state tax variable therefore implicitly assumes that each firm earns all its net revenues in its principal location, although this is clearly not the case for many firms. To minimize the potential influence of state tax rate measurement error, the state tax rates are only used in some of the analysis, as is made clear below.

\section{Data and summary statistics}

\subsection{Data sources and debt definitions}

The data are gathered from all three annual Compustat tapes: Full-Coverage; Primary, Secondary, and Tertiary; and Research. The Compustat sample contains observations for the years 1973 through 1994. This time frame is consistent with the availability of the state tax information in Fiscal Federalism, from which data ceased to be available after 1994 due to governmental budget 
cuts. As mentioned in Section 3, the tax rate calculation uses historically estimated drift and volatility terms, so the tax rate simulation procedure requires a "start-up" period. Consequently, the tax rates are calculated starting in 1980, leaving a seven-year start-up period for most firms. Each firm is formally required to have at least a three-year start-up period. So, for example, if a company first appears on the Compustat tapes in 1980, the first tax rate for that firm is calculated in $1983 .{ }^{10}$

The level of debt is defined as the debt-to-value ratio: the numerator is long-term debt plus debt in current liabilities; the denominator is the market value of the firm, defined as total assets minus book equity plus market equity. ${ }^{11}$ The mean (median) debt-to-value ratio is $21.3 \%(17.7 \%)$ over the sample period (see panel A of Table 1). The change in debt is defined in two separate ways. First, changes are measured simply as the first difference in the debt-to-value ratio. Second, change in debt is defined as long-term debt issuance (Compustat data item 111) minus long-term debt reduction (Compustat data item 114), the difference divided by market value of the firm. To the best of my knowledge, this is the first time the Compustat issuance and reduction data items have been used in a capital structure analysis. ${ }^{12}$

\subsection{Tax variables}

The Compustat ITC and NOL carryforward data are potentially important inputs in the tax

\footnotetext{
${ }^{10}$ For most firms, this implies that more historical observations are available to simulate late-in-the-sample tax rates, and so the precision of the estimated tax rates increases with year. This changing precision induces a form of time-series heteroskedasticity into panel data. Consequently, year-by-year analysis (in which any given year's results are not affected by the time-series element of varying tax rate precision) is performed to confirm the panel data results. The year-by-year estimates are corrected for cross-sectional heteroskedasticity (which can occur because the amount of available historical data varies across firms in any given year). equity.

${ }^{11}$ The results are qualitatively identical when market value is defined as the sum of book debt plus market
}

${ }^{12}$ I thank Mike Lemmon for making me aware of this data. 
calculations. In raw form, the ITC and NOL variables (annual data items 208 and 52, respectively) have many missing values. The ITC variable is set equal to zero if it is missing on Compustat. The treatment of NOLs differs depending on the definition of the dependent variable. In the incremental debt analysis, all historic decisions are taken as given. Therefore, historic book NOL carryforwards are used when defining the tax variable for incremental analysis, with missing values set to zero.

In the debt level analysis, rather than use Compustat NOL data, I assume that each firm starts with zero NOL carryforwards when it first enters the sample, and then accumulate carryforwards for each firm based on its own time-series of before-financing income. (This calculation assumes that carrybacks are taken as soon as possible.) This approach has the advantage of treating sample firms consistently, regardless of whether the NOL data are missing. A more subtle advantage is that the "cumulative effect" that past financing decisions have on book NOL carryforwards is eliminated. To see this, consider a firm that earns $\$ 50$ million in before-financing income each year but has $\$ 75$ million in annual interest expense, so its after-financing income is $-\$ 25$ million. After four years, this firm will have a $\$ 100$ million book NOL carryforward that results entirely from historic interest deductions (because book NOL carryforwards are based on after-financing income). Recall that the debt level analysis is based on before-financing income, and therefore should not rely on book NOLs. Instead, for the before-financing tax rates used in the debt level analysis, I accumulate NOLs from scratch using a firm's time-series of before-financing income.

To measure marginal tax benefits net of the personal tax penalty (see equations (2) and (3)), estimates of four variables are needed: $d, g, \alpha$, and $\tau_{\mathrm{p}}$. In the empirical work that follows, $d$, the dividend payout ratio, is estimated for each firm as the dividend distribution divided by a three-year moving average of earnings. ( $d$ is lagged one period because dividend policy is simultaneously determined with debt policy.) In the primary empirical specification, $d$ is allowed to vary across each 
firm in each year; in a separate specification $d$ is averaged across firms to determine a single economywide personal tax adjustment for each year. The portion of long-term gains that are taxable, $g$, is 0.4 before 1987 and 1.0 after, although the long-term capital gains rate, $g \tau_{p}$, has a maximum value of 0.28 after 1986. Following the lead of Feldstein and Summers (1979) and Gordon and MacKieMason (1990), I assume that the benefits of deferring taxable gains, $\alpha$, are 0.25 .

Finally, $\tau_{\mathrm{p}}$ is estimated as the personal tax rate for the "marginal investor," deduced from the difference in the returns on one-year tax-free municipal bonds and one-year taxable bonds (Poterba (1989) and Fortune (1996)): $\tau_{\mathrm{p}}=\left(\mathrm{R}_{\text {taxable }}-\mathrm{R}_{\text {tax-free }}\right) / \mathrm{R}_{\text {taxable }}$. Using the raw bond return data from Fortune (1996) where $\mathrm{R}_{\text {taxable }}$ is the one-year Treasury Bill rate and $\mathrm{R}_{\text {tax-free }}$ is the return on the one-year Prime Grade Solomon Brothers municipal note, the implicit tax rate $\tau_{\mathrm{p}}$ is inferred within different "tax regimes" (i.e., different statutory tax schedules): 47.4\% in 1980 and 1981, 40.7\% from 1982-1986, $33.1 \%$ in $1987,28.7 \%$ from $1988-1992$, and $29.6 \%$ starting in $1993 .{ }^{13}$

These modeling assumptions imply that there is no cross-sectional variation in $\tau_{\mathrm{p}}$. The crosssectional variation in tax benefits comes from the simulated corporate tax rate $\tau_{\mathrm{c}}$ and the dividend-

\footnotetext{
${ }^{13}$ Green (1993) models taxable and tax-exempt yield curves, estimating the marginal investor's tax rate in the process. Two aspects of Green's analysis lend credibility to the approach I use to infer $\tau_{\mathrm{p}}$ : 1) Green notes that it is better to use short-term yields to infer $\tau_{\mathrm{p}}$ because complicating factors, such as the deductibility of investment interest expense at the personal level, are more pronounced for longer maturities, and 2) Green estimates implicit tax rates within subperiods corresponding to different tax regimes. Chalmers (1998) and others show that the implicit personal tax rate is lower if inferred from long-maturity munis and taxables, implying a smaller personal tax penalty than I estimate. See Mankiw and Poterba (1996) for a discussion about alternative approaches to inferring $\tau_{\mathrm{p}}$; I use the "traditional model" because it is the most widely used [e.g., Scholes and Wolfson (1992)].

There is some debate about whether $\left(\mathrm{R}_{\text {taxable }}-\mathrm{R}_{\text {tax-free }}\right) / \mathrm{R}_{\text {taxable }}$ might proxy for $\tau_{\mathrm{c}}$ prior to the Tax Reform Act of 1986 [see Fama (1977), Miller (1977), Trczinka (1982), and Fortune (1988)]. However, $\left(R_{\text {taxable }}-R_{\text {tax-free }}\right) / R_{\text {taxable }}$ dropped sharply in the early 1980 s when the top statutory personal tax rate was substantially reduced but the corporate rate was left unchanged by the Economic Recovery Tax Act. Therefore, is seems unlikely that $\left(\mathrm{R}_{\text {taxable }}{ }^{-}\right.$ $\left.R_{\text {tax-free }}\right) / R_{\text {taxable }}$ proxies for the corporate rate. However, if $\left(R_{\text {taxable }}-R_{\text {tax-free }}\right) / R_{\text {taxable }}$ understates $\tau_{p}$, my estimates of the personal tax penalty are too low prior to 1987.

In an attempt to reduce noise in the inference of $\tau_{\mathrm{p}}$, I average monthly estimates within each statutory tax regime. Technically, there is a regime in 1991-1992 that I ignore. The mean $\tau_{\mathrm{p}}$ is $24.6 \%$ for that period, which is implausibly low given that the maximum statutory rate increased from $28 \%$ to $31 \%$ in 1991 . Rather than use $24.6 \%$, during 1991-1992 I keep $\tau_{\mathrm{p}}$ fixed at the $1987-1990$ rate of $28.7 \%$.
} 
payout term $d$ (which enters via $\tau_{\mathrm{e}}$ and the personal tax penalty).

About $60 \%$ of the sample have simulated before-financing tax rates near the top statutory rate in any given year (see panel A of figure 1). ${ }^{14}$ The effects of various tax regimes are clear from the figure, with the top statutory rate dropping from $46 \%$ to $34 \%$ after the Tax Reform Act of 1986, before increasing to $35 \%$ in 1992 . Firms with tax rates below the top statutory rate are either in a lower tax bracket (e.g., they earn $\$ 50,000$ in a given year), or, more likely, they have recently experienced negative earnings, or expect to experience them in the future. Overall, the distributions show a reasonable amount of time-series and cross-sectional variation in tax rates.

Whether economy-wide or firm-specific information is used, the expression in equation (3) is often positive, implying a net tax advantage to debt. However, the personal tax penalty is also generally positive [i.e., the bracketed term in equation (3) is positive because $\tau_{p}>\tau_{e}\left(1-\tau_{c}\right)$, and therefore the net (of personal taxes) marginal benefit of interest deductions is smaller than the corporate tax rate $\tau_{c}$. This can be seen by contrasting the distribution of tax rates in panel A of figure 1 with the distribution of net marginal benefits in panel B (which uses firm-specific information to adjust for personal taxes).

Perhaps the most striking feature of panel B is the similarity of the benefit distributions in 1984, 1988, and 1994. From panel A, we know that corporate tax rates shifted noticeably lower after the 1986 tax reform; the distributions in panel B reveal that the reduction in corporate tax rates resulting from tax reform was largely offset by changes in the personal tax penalty. That is, the distributions indicate there was very little time-series variation in tax incentives, net of the personal

${ }^{14}$ Before-financing tax rates (based on earnings before interest and taxes) measure the tax rate associated with the first dollar of interest deduction. After-financing tax rates (based on earnings after interest deductions are taken) measure the tax rate that apply if one additional dollar of interest deduction is taken. Although not shown in the figure, only about one-third of firms have after-financing tax rates near the top statutory rate (because many firms experience (or expect to experience) losses once financing deductions are considered). 
tax penalty. ${ }^{15}$ The primary effect of the Tax Reform Act was to tighten the distribution, with fewer firms having very large positive or very large negative marginal tax benefits. ${ }^{16}$

Other important information can be learned from the histograms in panel B: 1) relative to the marginal tax rates in panel $\mathrm{A}$, the marginal benefit distributions in panel $\mathrm{B}$ are shifted substantially to the left, reflecting the personal tax penalty, 2) although the time-series variation is modest, there is considerable cross-sectional variation in benefits across firms, and 3) both before and after tax reform, (i.e., in 1984 and 1988) a plurality of the sample firms face small but positive interest-financing benefits. The latter two points suggest that it may be possible to identify how tax incentives affect corporate debt policy, an issue pursued in Section 5.

The tax data are also listed in tabular form (see table 2). In panel A, information about the distribution of before- and after-financing tax rates is shown for each year 1980-1994. Ignoring the personal tax penalty, the median before-financing tax rate is almost always the top statutory rate. In contrast, the median after-financing tax rate is substantially lower than the top rate, confirming that using debt endogenously lowers a firm's tax rate. Considering the personal tax penalty, the median tax advantage to debt is often near $10 \phi$ on the dollar for the first dollar of interest deduction (beforefinancing MTRs in leftmost columns of panel A). In contrast, the median value of the last dollar of interest deduction is often worth almost nothing (considering personal tax penalty, after-financing

\footnotetext{
${ }^{15}$ The mean net benefit to interest deductions increased by about 200 basis points from 1984 to 1988 , which can be compared to an average debt-to-value increase of about 300 basis points. The primary factors that led to an increase in the net benefit were the decrease in personal tax rate on interest income (which declined from $40.7 \%$ to $28.7 \%$ ) and the elimination of favored treatment for capital gains. The factors that led to an off-setting decrease in the net benefit to interest deductions include the decline in the top statutory corporate rate (from $46 \%$ to $34 \%$, which led to a decrease in the mean simulated rate from $38.0 \%$ to $25.9 \%$ ) and declining dividend payout (from a mean of $24.0 \%$ to $20.5 \%$ ). The overall tax on equity income $\tau_{\mathrm{e}}$ declined from $12.8 \%$ to $11.4 \%$. These data are shown in panel B of table 2.

${ }^{16}$ It is possible that some firms "switched places" in the distributions before and after tax reform, providing more incentive to alter debt policy than is visually obvious in the histograms. This is a good topic for future research.
} 
MTRs). This last result is intriguing because it is consistent with the typical firm choosing optimal debt policy by equating the (near-zero) benefit of the last dollar of debt to the marginal cost.

The mean annual values of dividend payout, $\tau_{\mathrm{p}}, \tau_{\mathrm{e}}$ and the before- and after-financing tax rates are shown in panel B of table 2 (see also figure 2). The mean personal and corporate tax rates have fallen noticeably over the sample period. Given that the reductions are of the same general magnitude, this suggests that in the aggregate tax incentives have not changed substantially since 1980; this is confirmed by noting the relatively flat graphs for tax rates adjusted for the personal tax penalty (see the bottom two lines in figure 2). Modest exceptions are notable when the incentive to use debt 1) increased when the personal tax penalty was reduced in conjunction with the 1981 tax act, and 2) increased when the reduction in the personal tax penalty more than offset the reduction in corporate taxes resulting from the 1986 tax act. The average dividend payout and tax on equity are fairly constant over most of the sample.

This paper investigates whether personal taxes affect corporate financing decisions. As stated previously, the cross-sectional variation in the personal tax penalty comes from the dividend-payout ratio $d$. This suggests that it might be interesting to examine the cross-sectional variation in tax benefits as a function of $d$. The personal tax penalty is most severe for firms that do not pay dividends $(d=0)$; this can be seen by noting that the net-of-personal-taxes benefit (BEN) of a dollar

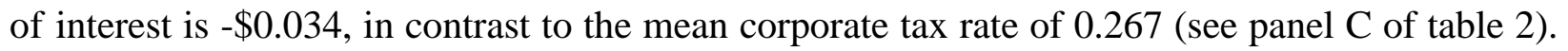
The personal tax penalty declines as $d$ increases, while the net tax benefit of debt increases. At the extreme, the personal tax penalty is least severe for firms that pay all earnings out as dividends $(d=1)$, in which case the net-of-personal-taxes benefit of a dollar of interest is $\$ 0.211$, in comparison to a mean corporate tax rate of 0.326 . 


\subsection{Control variables}

A collection of non-tax control variables are used to hold "all else equal" in the capital structure regressions so the analysis can isolate tax effects. One set of variables is designed to proxy for the costs of financial distress, to capture the notion from the trade-off theory that firms balance the benefits of debt financing with the financing-induced cost of distress. One variable linked to expected distress costs is Altman's (1968) Z-score. I examine the modified Z-Score used by MacKieMason (1990) and Graham, Lemmon, and Schallheim (1998), which is defined as $3.3 \frac{\text { EBIT }}{\text { TotalAssets }}+1.0 \frac{\text { Sales }}{\text { TotalAssets }}+1.4 \frac{\text { Ret. Earnings }}{\text { TotalAssets }}+1.2 \frac{\text { Working Capital }}{\text { TotalAssets }}$, where EBIT is earnings before income and taxes. The latter authors also use a cost variable that is designed to capture the expected loss due to distress: ECOST interacts a term related to the coefficient of variation of the firm's earnings (to proxy for the likelihood of financial distress) with the firm's level of asset intangibility (to proxy for the proportion of firm value likely to be lost in liquidation). The coefficient of variation in earnings is measured as the standard deviation of the first difference in the firm's historical EBIT divided by the mean level of the book value of total assets. ${ }^{17}$ Asset intangibility is defined as the sum of research and development and advertising expenses divided by sales, with the values set to zero if the data are missing.

Two other variables that can help identify firms with relatively large financial distress costs are NODIV (a dummy equal to one if the firm does not pay dividends) and OENEG (a dummy equal to one if the firm has negative owners equity). Firms that do not pay dividends are also likely to be subject to large informational asymmetries, perhaps causing them to prefer debt over equity financing

${ }^{17} \mathrm{ECOST}$ is divided by the mean level of assets rather than the mean level of earnings to circumvent the problem in interpreting the coefficient of variation when the mean level of earnings is negative. In general, the level of earnings and the level of book assets are positively correlated. This measure of earnings variability is also used by MacKie-Mason (1990). 
(Myers and Majluf (1984)). If OENEG measures future (past) financial distress, it should be negatively (positively) related to debt usage (the latter because market equity will be depressed).

"Growth" firms with excellent investment opportunities are often said to have high debt financing costs. For example, Myers (1977) argues that shareholders of a firm with risky fixed claims in its capital structure will potentially forego positive NPV investments if project benefits accrue to the firm's existing bondholders; this problem is likely to be more severe among growth firms. Tobin's $q$-ratio is used to measure the growth prospects of the firm. Given that the q-ratio is difficult to calculate, the approximate q-ratio defined by Chung and Pruitt (1994) is used; they show that the approximate q is very highly correlated with, but much easier to calculate than, the version of Tobin's q-ratio used by Lindenberg and Ross (1989). ${ }^{18}$ The approximate q-ratio is $\frac{\text { Preferred Stock }+ \text { market common equity }+ \text { book long-term debt }+ \text { net short term liabilities }}{\text { Total assets }}$ For the same reason that MacKie-Mason modified Z-score (because the variable is used in capital structure regressions with debt in the numerator of the dependent variable), long-term debt is excluded from the numerator of the approximate q. ${ }^{19}$

A firm with extensive collateral can likely borrow on favorable terms and hence have lower borrowing costs. PPE-to-assets measures collateral and is defined as net property, plant and equipment divided by total assets. It is sometimes said that large firms have lower ex ante costs of financial distress, perhaps because they are more diversified or because their size allows them to "weather the storm." Large firms may also suffer lower informational costs associated with borrowing. Firm size is gauged with the natural log of real sales. Real sales are deflated by the

\footnotetext{
${ }^{18}$ The Lindenberg and Ross (1989) version of q is generally thought of as being "theoretically correct" [see Chung and Pruitt (1994)], although quite arduous to calculate.

${ }^{19}$ The q-ratio is deflated by total assets to be consistent with the specification of the other variables used in the analysis. The qualitative conclusions do not change if debt is left out of the denominator.
} 
implicit price deflator and expressed in millions of dollars prior to taking the logarithm.

Finally, liquidity and cash flows are sometimes linked to costs of borrowing. The most basic notion is that illiquid firms face higher ex ante borrowing costs. However, this effect may be offset to some extent by a cost associated with free cash flow. For example, Jensen (1986) theorizes that the managers of firms with high free cash flows may lack discipline. An implication from Jensen's theory is that firms subject to this free-cash-flow cost should issue debt (thereby more aggressively pursuing interest deductions) to discipline management into working more efficiently. I use operating-income-to-assets (cash flow from operations deflated by total assets) to measure liquidity and cash flow position. Myers (1993) notes that perhaps the most pervasive empirical capital structure regularity is the inverse relation between debt usage and profitability measures such as operating-income-to-assets.

Table 1 presents summary statistics for the variables of interest. There are 65,429 observations with non-missing values for the tax and control variables. As can be seen from the table, each of the variables exhibits reasonable variation across the sample (panel A). The largest correlations between debt-to-value and the explanatory variables are for OENEG (correlation of 0.186), PPE-to-assets $(0.278)$ and the log of real sales (0.149). The tax-benefit variable and debt-tovalue have a positive correlation, albeit fairly small (0.063). The next section examines whether the relation between tax incentives and debt usage is significant in a multivariate setting.

\section{The effect of corporate and personal taxes on capital structure decisions}

\subsection{Capital structure regressions}

As stated in the introduction, there is mounting evidence that taxes affect the decision to finance with debt. The extant literature, however, does not focus on how the personal tax penalty 
affects individual firms' capital structure decisions. Indeed, Gordon and MacKie-Mason (1990, p. 96) state that "no one has attempted to estimate directly the relationship between the debt incentive of equation (3) and firm debt ratios" (equation number changed to be consistent with mine). In this section, regressions are used to determine whether a firm-specific personal tax penalty helps explain firm-by-firm debt policy. An economy-wide personal tax adjustment is also performed and contrasted with the firm-specific adjustment.

The first two sets of models regress debt-to-value on the control variables and two tax variables: the before-financing federal tax rate and the state tax rate (see Table 3). Two versions of the model are examined: column (3a) corrects for a firm-specific personal tax penalty in the manner presented in equation (3), and column (3f) uses the simulated corporate tax rate uncorrected for the personal tax penalty. All the variables in both specifications have the expected sign, although Z-score and operating-income-to-assets are insignificant. The state tax variable is significant in both specifications; however, due to measurement issues related to the state tax variable, this result should be interpreted as suggestive but unreliable. ${ }^{20}$ Most importantly for the purposes of this paper, the simulated federal tax benefit coefficient is positive and significant in both specifications.

Several regressions are performed to exploit the panel nature of the data. Column (3b) contains results for a regression that repeats the (3a) specification but includes annual dummies to remove any unmodeled time-effects. Accounting for time-effects does not affect the inference about any of the variables. An alternative way to hold time-series effects constant is to use only one

\footnotetext{
${ }^{20}$ Recall from Section 3B that the state tax variable is calculated with Compustat's description of the firm's principal location, which is not necessarily where it pays the majority of its taxes. For this reason, the state tax results are not overemphasized due to potential measurement error.

In a separate specification, the state tax variable is replaced by the statutory state tax rate to ensure that the variation in the state tax variable is not overly affected by its dependence on $\left(1-\tau_{\text {Federal }}\right)$. The estimated coefficient on the statutory state tax rate is negative and significant, causing concern about the construction of the state tax variable. The coefficients on the other variables are qualitatively unchanged.
} 
observation per firm, where that observation is the mean time-series value for each firm. These results show strong state and federal tax effects (column (4a) of table 4). Next, the federal and state tax variables are modified to allow for time-varying federal and state tax coefficients (column (3c)). The federal tax variable is positive and significant in each of the 15 years 1980-1994, with coefficients ranging between 0.035 and 0.168 . In contrast, the state tax variable is positive and significant in only 7 of 15 years, with coefficients ranging from -0.079 and 0.520 . Overall, these results indicate that when time-series influences are held constant, the cross-sectional variation in tax rates allows for the identification of tax effects.

Column (3d) of table 3 contains the results of a time- and firm-fixed-effects regression. The firm-fixed-effects are modeled by expressing each explanatory variable net of its firm-specific timeseries mean, which is equivalent to including a dummy for each firm. Now, the federal tax effects disappear (in fact, have the wrong sign), although the majority of the other variables have the expected sign. When time-varying tax coefficients are allowed (column (3e)), the federal tax benefit is significant and positive in 13 of 15 years. ${ }^{21}$ The state tax variable is positive and significant in only 7 of 15 years.

The results shown in columns (3b)-(3e) indicate that cross-sectional, not time-series, variation in tax rates allows one to identify positive tax effects. Once cross-sectional fixed-effects are held constant, it is no longer possible to reliably identify tax influences. (One explanation for not finding time-series results is lack of sufficient temporal variation; although personal and corporate tax rates both decline substantially during the sample period, they do so in tandem, indicating that the net

\footnotetext{
${ }^{21}$ In the column (3d) specification, the respective firm-specific time-series mean is subtracted from each of the explanatory variables. In the column (3e) specification, the time-series mean is not subtracted from timevarying tax variables, else the regression matrix would be singular; that is, one can not simultaneously control for time- and firm-fixed effects from the tax variables and allow for time-varying tax coefficients.
} 
benefit of interest deductions has been fairly constant through time. In Section 5.6, I examine whether firm-specific changes in debt are related to tax incentives.) Thus, we are able to identify tax effects solely because of the cross-sectional variation in 1) the simulated tax rates, and 2) the personal tax penalty. Recall that the variation in the personal tax term comes entirely from using firm-specific dividend-payout ratios. Therefore, several robustness checks are performed in the following sections to help clarify whether the apparent tax effects just documented are the result of corporate tax incentives and/or personal tax disincentives to use debt.

The pooled cross-sectional time-series regressions can be affected by standard errors that are biased due to time-series serial or cross-sectional correlation in the residuals. To side-step the timeseries problem, a series of annual regressions are run for each year 1980-1994 (see table 5). (The standard errors in this and all the regressions are corrected for heteroskedasticity using White's (1980) correction.) The adjusted $\mathrm{R}^{2} \mathrm{~s}$ range from $15 \%$ to $29 \%$ for the 15 annual regressions. ${ }^{22}$ The coefficients on the simulated tax variable that corrects for a firm-specific personal tax penalty are positive in all 15 years, and significant at a 5\% level in 13 of 15 years (see panel B of table 5, left column). (The only years in which the coefficient is not significant are 1981 and 1986, which could be related to adjustments firms made in anticipation of and in reaction to tax reforms. The tax simulation procedure assumes that firms have no foresight about future tax regimes. For example, although in 1986 it was widely known that tax rates would change in 1987, and firms may have been adjusting their capital structures in anticipation, the simulation procedure does not alter the statutory tax schedule until the change officially occurs.) In contrast, the tax coefficients in the annual regressions that use a simulated tax variable that does not correct for personal taxes are positive and analysis.

\footnotetext{
${ }^{22}$ Because of the unstable behavior of the state tax variable in Table 3, I drop it from the year-by-year
} 
significant at the $5 \%$ level in only 11 of 15 years (middle column of table 5).

\subsection{Is it important to adjust for personal taxes?}

In the annual regressions in table 5, adjusting for the personal tax penalty appears to be an important part of identifying tax effects (because it leads to a larger number of positive, significant tax coefficients). To formalize this notion, a non-nested regression test is performed to determine whether the "net of personal taxes" approach dominates the "ignoring personal taxes" specification. As described in Davidson and MacKinnon (1993, p. 382), the first step involves estimating the model in column (3f) of table 3 (except that the state tax variable is excluded) using a tax variable that ignores the personal tax penalty. The tax coefficient from the first step is then multiplied by the firststep tax variable, creating a "predicted 'ignoring personal taxes' tax effect" for each observation. This term is then included in a second step that estimates an enhanced version of the column (3a) regression, where the specification is

$$
\frac{\text { Debt }_{\text {Value }_{i t}}=\begin{array}{r}
\alpha+\gamma \beta \text { BEN }_{i t}+(1-\gamma) \\
+ \text { predicted 'ignoring pers. taxes' effect }_{i t} "
\end{array}}{+ \text { 'controls }_{i t}+\epsilon_{i t}}
$$

with $\mathrm{BEN}_{\mathrm{it}}$ being the net of personal taxes benefit of interest deductions for firm $i$ in year $t$. If $\gamma=1$, the "net of personal taxes" approach is said to statistically dominate the "ignoring personal taxes" specification. The untabulated results indicate that $\beta(\gamma)$ has a coefficient of 0.235 (1.11) with a standard error of $0.143(0.089)$. Thus, $\gamma$ is statistically indistinguishable from 1.0 , and the $\beta$ coefficient indicates that net tax benefits are positive and statistically significant in a one-sided t-test. This implies that it is important to adjust for personal taxes when investigating capital structure decisions. 
At this point, an investigation is performed to see how important it is to use firm-specific information to calculate the personal tax penalty, rather than using economy-wide information as has been done in previous work (e.g., Gordon and MacKie-Mason (1992), Rajan and Zingales (1995), Graham (1996a), and Graham, Lemmon, and Schallheim (1998) all adjust for personal taxes in a way that does not vary cross-sectionally across firms.) In this analysis, a tax variable is used with a personal tax adjustment that only accounts for economy-wide differences in equation (3); that is, the dividend-payout is averaged across firms within each year to determine a single economy-wide adjustment that is applied to all firms. This approach produces annual coefficients that are significant at a 5\% (10\%) level in 11 (12) of 15 years (see rightmost column in Table 5). ${ }^{23}$ Overall, these results are weaker than those based on the firm-specific adjustments in the sense that less coefficients are positive and significant. Therefore, informally, using firm-specific information to gauge the personal tax penalty appears to improve the ability of regressions to detect tax effects in financing decisions. However, the Davidson and MacKinnon non-nested regression test does not indicate that the "firmspecific" adjustment statistically dominates the "economy-wide adjustment."

The strictest interpretation of the informal finding (that firm-specific information is important) is that the arbitrage relation between stock and bond returns (with respect to adjusting for the personal tax penalty) is determined within tax clienteles, rather than by a single economy-wide investor; tax clienteles could form if investors invest in particular stocks based on dividend payout ratios. An alternative view is that there is some element of firm-specific information that is important, even if there are not tax clienteles; for example, using firm-specific information may represent a crude

\footnotetext{
${ }^{23}$ In a separate analysis, an economy-wide adjustment is used that assumes that dividend-payout is zero for all firms. This approach has annual coefficients that are positive and significant at a $10 \%$ level in 10 of 15 years.
} 
risk-adjustment that proves helpful when examining financing policy in the cross-section. ${ }^{24}$ Investigating these possibilities may prove to be an intriguing area for future research.

\subsection{Robustness of the tax results to statistical issues}

As previously mentioned, the standard errors in the panel regressions may be biased downward due to time-series or cross-sectional correlation in the residuals. The year-by-year regressions show that the tax results hold up when the potential time-series correlation problem is avoided. Two additional checks are performed to ensure that possible cross-sectional correlation in the errors is not biasing the conclusions in the year-by-year analysis. First, a generalized method of moments (GMM) error correction is performed. The model is estimated using Parzen's (1957) weights [see Andrews (1991)] in Hansen's (1982) generalized method of moments. This approach estimates consistent coefficients in the presence of conditional heteroskedasticity. Further, if the data are cross-sectionally stationary and ergodic (i.e., the sample moments converge to the population moments), the GMM standard errors are consistent with respect to correlation across residuals. The GMM regressions yield positive tax coefficients that are significant at a 5\% level in 13 of 15 years, and significant at a 10\% level in 14 of 15 years. As a second check, a Fama and MacBeth (1973) type of analysis is also performed. That is, the mean of the coefficients is calculated using each annual coefficient as a single observation. The average coefficient is 0.123 with a t-score of 5.3 (corrected for first-order serial correlation), providing strong evidence of positive tax effects that are robust with respect to possible problems caused by cross-correlation in the residuals.

\footnotetext{
${ }^{24}$ It is important to document that using a firm-specific dividend-payout ratio does not introduce a strong, "non-tax" relation between debt policy and the tax variable. If dividend payout is included as a separate explanatory variable it has a positive, significant coefficient; however, the inference on the tax variable is unchanged.
} 
The analysis is also repeated using a tobit specification. This is appropriate because debt-tovalue is censored at values of zero and one. The tobit analysis yields positive tax coefficients that are statistically significant in all 15 years. The tobit results are not presented as the main specification because I want to correct for the potential problems due to correlation in the errors (see above) and also for ease of interpretation of the marginal effects of the explanatory variables. By not using tobit in the main specification, however, the coefficients in the tables could be biased downward (i.e., against finding significant tax results).

The analysis is also repeated using debt-to-assets as dependent variable, rather than using debt-to-value. The results are generally consistent with those in the tables but not as strong statistically. The pooled time-series cross-sectional regression coefficient is positive and significant at a 5\% level. Twelve of the annual coefficients are positive, although only eight are statistically significant. A Fama-MacBeth analysis of the annual coefficients indicates that the tax effect is positive and significant at a $5 \%$ level.

\subsection{Issues related to the marginal investor}

The approach used thus far 1) specifies $\tau_{\mathrm{p}}$ as the tax rate implicit in the difference in the yields

between municipal bonds and T-bills, 2) assumes that $\tau_{\text {dividends }}=\tau_{\mathrm{p}}$, and 3) assumes that $\tau_{\text {cap. gains }}$ is a function of tax breaks provided to capital gains, when they exist. Poterba (1997) provides an alternative approach to estimating these tax rates. Using Flow of Funds data, Poterba imputes a weighted average of marginal tax rates for various asset classes, where the averaging is done across sectors of the economy (i.e., households, insurance companies, banks, etc.). Combining Poterba's estimates of $\tau_{p}$, $\tau_{\text {cap.gains }}$, and $\tau_{\text {dividends }}$ from his table A-1 into a new measure of the personal tax penalty, and using equation (3), the specification in column (3a) is reestimated using this alternative tax 
variable. The results show that taxes have a significant and positive effect on capital structure decisions (see column (4b) of table 4). This indicates that the tax results are robust to different measures of the personal tax penalty.

The approach used thus far has ignored potential differences between bank debt and publically traded bonds. When all debt is lumped together, an implicit assumption is made that interest rates on bank debt and public bonds are identically equilibrated to the return on municipal bonds. One might wonder whether interest rates on public and bank debt are determined identically, or whether a wedge could be driven between them due to some imperfection in borrowing markets. While Compustat data does not allow for a pure "public" versus "bank" dichotomization, it is possible to identify firms with credit ratings versus those without. (Compustat provides Standard and Poor's credit ratings starting in 1985, so the analysis in this paragraph is restricted to 1985-1994.) If one assumes that firms with (without) credit ratings exclusively use public (bank) debt, it is possible to investigate this issue. Results in column (4c) of table 4 show that there are strong positive tax effects among firms with credit ratings. The overall explanatory power of this specification is quite large, with an adjusted $\mathrm{R}^{2}$ of $50 \%$. Similarly, results in column (4d) show that there are positive tax effects among firms without credit ratings, although the tax coefficient is only about one-third the size of the tax coefficient in column (4c). On the one hand, the smaller coefficient could be interpreted as evidence that bank and public debt are priced separately in equilibrium, perhaps by different marginal investors. On the other hand, the differences in the tax coefficients may result from unmodeled differences between firms that have and do not have credit ratings (such as risk). Either way, positive tax effects are identified for both subsets of firms.

\subsection{Directly estimating the effect of the personal tax penalty}


The story thus far is that there may be tax clienteles, with firm-specific marginal investors responding to their personal tax incentives as they equilibrate the prices of debt and equity separately for each firm. Based on my approach to quantifying equation (3), the only cross-sectional variation with personal tax consequences comes from firm-specific dividend payout $(d)$; that is, my approach does not allow for cross-sectional variation in $\tau_{\mathrm{p}}$, even though it makes sense that marginal investors choose the securities in which they invest based on their heterogeneous personal income tax rates.

Auerbach (1983) estimates a capital asset pricing model that allows for heterogeneity in investors' personal tax characteristics. He finds that high-tax rate investors gravitate to stocks with low dividend yields. Auerbach also estimates a parameter $\theta$ that captures the "differential tax rate between dividends/interest income and capital gains" (p. 119, "/interest income" added); in my lingo, $\theta$ measures the personal tax penalty. Auerbach finds that the cross-sectional variation in $\theta$ is explained by a quadratic specification of firm-specific dividend-price ratios but not by other firm characteristics. Given Auerbach's results, it is important to investigate whether my specification of the personal tax penalty varies sufficiently across firms. One might suspect that my specification is adequate because my personal tax penalty varies by dividend-payout, which is fairly similar to dividend-price — but the issue deserves further investigation.

A year-by-year analysis is performed that replaces the net tax benefit variable from column (3a) of table 3 with two terms: the simulated corporate tax rate $\tau_{c}$, and a separate personal tax penalty variable: $\tau_{\mathrm{p}}-\left(1-\tau_{\mathrm{c}}\right) \tau_{\mathrm{e}}$ [see equation (3)]. The corporate tax variable is expected to have a positive coefficient in this regression and, if its cross-sectional variation is sufficient, the personal tax penalty should have a negative coefficient. The results indicate that the corporate tax rate coefficient is positive in all fifteen years, and significant in twelve (see Table 6). More importantly for this section, the personal tax penalty exerts a negative influence on debt usage in all fifteen years, significantly so 
in fourteen. To the best of my knowledge, this is the first direct estimation of the effect of the personal tax penalty on capital structure decisions.

The results just reported suggest that the personal tax penalty has sufficient variation across firms as specified, even though it is based on dividend-payout rather than dividend-yield. Nonetheless, to determine whether the personal tax penalty $\tau_{p}-\left(1-\tau_{c}\right) \tau_{e}$ lacks variation along the lines identified by Auerbach (1983), it is interacted with dividend-price and (dividend-price) ${ }^{2}$. These latter variables are also added to the specification as stand-alone terms. Thus, the specification for this analysis is

$$
\frac{\text { Debt }}{\text { Value }}=\begin{gathered}
\alpha+\beta \tau_{c}+\left(\gamma_{1}+\gamma_{2} \frac{D}{P}+\gamma_{3}\left(\frac{D}{P}\right)^{2}\right)\left(\tau_{p}-\left(1-\tau_{c}\right) \tau_{e}\right)+ \\
\delta_{1} \frac{D}{P}+\delta_{2}\left(\frac{D}{P}\right)^{2}+\zeta^{\prime} \text { controls }+\epsilon
\end{gathered}
$$

If the estimated $\gamma_{2}$ and $\gamma_{3}$ are non-zero, there is cross-sectional variation in the personal tax penalty not captured by my specification. If $\gamma_{2}, \gamma_{3}, \delta_{1}$, and $\delta_{2}$ all equal zero, this could be interpreted as indicating that my specification captures the relevant variation in the personal tax penalty. Either way, the expected signs on $\beta$ and $\gamma_{1}$ are positive and negative, respectively.

The untabulated regression results indicate that $\beta$ is generally positive as expected, and significant in 10 of 15 years. Also as expected, $\gamma_{1}$ is negative in all fifteen years, and significant in 12 of 15 . The $\gamma_{2}\left(\gamma_{3}\right)$ coefficient is generally negative (positive) and significantly different from zero in $8(11)$ of 15 years. Finally, $\delta_{1}$ and $\delta_{2}$ are each significantly different from zero in only 6 years, none after 1986. Overall, even in the presence of dividend-price and its square, the positive (negative) influence of corporate (personal) taxes on capital structure decisions is identified, indicating that there is reasonable cross-sectional variation in these variables. There is, however, some evidence of 
additional cross-sectional variation in personal tax characteristics beyond what is captured in the personal tax penalty as specified.

An alternative specification of the personal tax penalty based on Auerbach (1983) is also examined. In his equation (17.15), Auerbach estimates that $\theta$ is equal to $1.071-123.9 \frac{\text { div }}{\text { price }}+$ $3483.9\left(\frac{\text { div }}{\text { price }}\right)^{2}$. An untabulated analysis is performed using this estimate of $\hat{\theta}$ in place of the usual measure of the personal tax penalty. The estimated regression coefficient is negative and significant in nine of fifteen years.

\subsection{Changes in debt}

So far, the analysis has focused exclusively on whether taxes affect corporate debt levels. While using debt ratios may be reasonable given the nature of Compustat data (see section 2), in this section I examine whether the results also hold for changes in debt. For the first specification, the change in the debt-to-value ratio is used as dependent variable. The first-difference of the right-side variables are used as explanatory variables, except for the tax benefits term where the lagged variable from equation (3) is used (and is based on after-financing income). The logic behind this specification is that firms with high tax rates will obtain additional financing in the form of debt, while the control variables hold constant non-tax changes in firm characteristics that may lead to capital structure changes. A pooled cross-sectional time-series regression shows positive and statistically significant tax effects (panel A of table 7). Year-by-year analysis identifies positive, significant tax coefficients in 10 of 14 possible years (panel B).

A separate specification measures the change in debt using the net increase in long-term debt from the Sources and Uses of Funds statement (right column of table 7). The tax coefficient in the pooled regression is positive and significant (and is twice as large as the coefficient based on changes 
in debt-to-value). The annual coefficients are positive and significant in all 14 years. Overall, the results indicate that the tax incentives identified in this paper are robust to whether the analysis examines changes in or levels of debt.

\subsection{Economic significance of the tax effects}

To get a feel for the economic significance of the implied tax effects, the estimated coefficient for each variable (from column (3a) in table 3 ) is multiplied by the associated sample mean. For the tax variables the mean values for 1994 are used (0.036 federal (net of personal taxes), 0.033 state). By summing the products of the coefficients and mean values, the implied "average" debt-to-value ratio is $20.8 \%$ (see table 8 ). When the mean tax rates are replaced by the highest tax rates in 1994 (0.277 federal, 0.099 state) the "highest tax rate" debt ratio is $24.1 \%$. Analogously, the "lowest tax rate" debt ratio is $18.1 \%$. Thus, the estimated tax coefficient implies that highest tax rate firms will, on average, have debt-to-value ratios that are 600 basis points higher than debt ratios for lowest tax rate firms. Analogously, when the tax rates are replaced by "mean plus one standard deviation" and "mean minus one standard deviation," the debt-to-value spread between high and low tax rate firms is 340 basis points. Due to the usual errors-in-variables problem, these figures may be biased downward if the simulated tax rate is estimated imprecisely (because the tax coefficient would be biased downward). Moreover, these estimates of the economic importance of tax effects are conservative in the sense that the column (3a) tax coefficient of 0.07 is smaller than the estimated tax coefficient in many of the other regression specifications.

A similar experiment is performed to estimate the economic effect of the personal tax penalty. In this analysis, the mean of the raw tax rate ignoring the personal tax penalty is plugged in (still using the estimated coefficients from column (3a) ) to determine that the "average" debt ratio is $22.3 \%$. Analogously, the "highest tax rate firm" debt ratio is $24.9 \%$. These numbers compare to 
estimates of $20.8 \%$ and $24.1 \%$, respectively, when personal taxes are considered; therefore, the effect on average debt ratios of the personal tax penalty is moderate, ranging between 100 and 200 basis points. $^{25}$

\section{Conclusion and discussion}

In this paper, marginal tax rates are simulated to account for uncertainty in taxable income, as well as the tax-loss carryback and carryforward, ITC, and AMT features of the tax code. The simulated tax rates are then adjusted for the personal tax penalty associated with interest income and used to test whether tax incentives affect corporate financing decisions. When firm-specific information is used to calculate the personal tax penalty, the capital structure regressions show strong tax effects, with high tax rate firms having more debt in their capital structures than low tax rate firms. In a series of 15 annual regressions, the tax coefficients have the correct sign and are statistically significant in almost every year. Additional investigation shows that adjusting for personal taxes is statistically important, relative to ignoring personal taxes. This result has important implications for researchers controlling or testing for tax effects. The analyses also indicate that the personal tax adjustment can instead be performed on an economy-wide basis, although less of the annual tax coefficients are positive and significant.

The tax results are robust to a wide variety of specifications. For example, the findings hold for firms with and without credit ratings, when tax incentives are measured using the "average marginal tax rates" of Poterba (1997), and when the variation in tax incentives is purely crosssectional. The only time the results do not hold is when firm-fixed-effects are controlled, indicating that the time-series variation in tax rates is not sufficient to identify tax effects (perhaps because the

\footnotetext{
${ }^{25}$ These are rough estimates. For example, if the "no personal taxes on interest income" scenario were to truly occur, the whole equilibrium would shift and the marginal effect of tax incentives (i.e., the estimated tax parameter) would most likely differ from that in table 3.
} 
time-series is fairly short).

The results offer evidence against Miller's (1977) "no tax-induced optimal capital structure" conclusion. Miller argues that, at the margin, the personal tax penalty exactly offsets the corporate tax advantage of debt financing, leaving individual firms indifferent between using debt and equity financing. If Miller's idea holds precisely, it should not be possible to document cross-sectionally significant tax effects like those found here. The results in this paper suggest that the personal tax penalty reduces, but does not eliminate, the tax incentive to use debt.

Finally, the recent 1997 tax legislation included a capital gains tax break (reducing the top rate from $28 \%$ to $20 \%$ for assets held 18 months, later retroactively changed to 12 months, and further to $18 \%$ starting in the year 2000) without changing the statutory corporate tax schedule. The reduction in the capital gains tax rate increases the personal tax penalty associated with debt financing. Using the estimated coefficients from the pooled regression (column (3a) of table 3), the analysis in this paper implies that the reduction in capital gains tax rates should lead to a very small reduction in the amount of debt used in the economy: a debt ratio of $20.7 \%$ for the average firm, versus $20.8 \%$ before the 1997 legislation.

Two issues should be investigated in future research. First, my specification allows for crosssectional variation in the personal tax penalty only through firm-specific dividend-payout ratios. Although this modeling of the personal tax penalty is somewhat limited, the results are corroborated in a wide variety robustness checks. Still, it would be very interesting if one could investigate the effect of the personal tax penalty in a setting or experiment that allows for more cross-sectional variation in, and precise estimation of, personal tax characteristics. Second, this paper does not find any evidence that time-series changes in personal tax rates affect corporate financing decisions. This issue should be investigated further using a longer time-series of data, or in an alternative setting, that allows for more time-series variation in the personal tax characteristics of the marginal investor(s). 


\section{$\underline{\text { Acknowledgements }}$}

I thank Peter Fortune for providing the bond return data and Ron Bagley, Rick Green, Mike Lemmon, Ed Maydew, Philip O’Conner, Mitchell Petersen, Jim Poterba (the editor), Oded Sarig, two anonymous referees, and seminar participants at the Eighth Annual Conference on Financial Economics and Accounting for helpful feedback. All errors are my own. The simulated tax rates that are used in this paper are available at http://www.duke.edu/ jgraham. 


\section{References}

Andrews, D., 1991, Heteroscedastic and autocorrelation consistent covariance matrix estimation. Econometrica 59, 817-858.

Altman, E., 1968, Financial ratios, discriminant analysis, and the prediction of corporate bankruptcy. Journal of Finance 23, 589-609.

Altshuler, R., and Auerbach, A., 1990, The significance of tax law asymmetries: An empirical investigation. Quarterly Journal of Economics CV, 61-86.

Auerbach, A., 1983, Stockholder tax rates and firm attributes. Journal of Public Economics 21, 107-127.

Auerbach, A., and Poterba, J., 1987, Tax-loss carryforwards and corporate tax incentives, in Feldstein, M., (Ed.), The Effects of Taxation on Capital Accumulation. University of Chicago Press, Chicago, IL, pp. 305-338.

Bali, R., and Hite, G., 1998, Ex dividend day stock price behavior: discreteness or tax-induced clienteles? Journal of Financial Economics 47, 127-159.

Bradley, M., Jarrell, G., Kim, E.H., 1984, On the existence of an optimal capital structure. Journal of Finance 39, 857878.

Chalmers, J., 1998, Default risk cannot explain the muni puzzle: Evidence from municipal bonds that are secured by U.S. Treasury obligations. Review of Financial Studies 11, 281-308.

Chung, K., and Pruitt, S., 1994, A simple approximation of Tobin's q. Financial Management 23, 70-74.

Dhaliwal, D., Trezevant, R., and Wang, S., 1992, "Taxes, investment-related tax shields and capital structure. Journal of the American Taxation Association 14, 1-21.

Elton, E., and Gruber, M., 1970, Marginal stockholder tax rates and the clientele effect. Review of Economics and 
Statistics 52, 68-74.

Davidson, R., and MacKinnon, J., 1993, Estimation and inference in econometrics. Oxford University Press, Oxford.

Desai, M., 1997, A multinational perspective on capital structure choice and internal capital markets. Harvard working paper.

Fama, E., and MacBeth, J., 1973, Risk, return, and equilibrium: Empirical tests. Journal of Political Economy 71, 607636.

Fama, E., 1977, A pricing model for the municipal bond market. Working Paper, University of Chicago.

Farrar, D., and Selwyn, L., 1967, Taxes, corporate policy, and return to investors. National Tax Journal 20, 444-454.

Feldstein, M., and Summers, L., 1979, Inflation and taxation of capital income in the corporate sector. National Tax Journal 41, 219-233.

Fiscal Federalism, 1981-95, U.S. Advisory Commission on Intergovernmental Relations, Washington DC.

Fortune, P., 1988, Municipal bond yields: Whose tax rates matter, National Tax Journal 41,219-234.

Fortune, Peter, 1996, Do municipal bond yields forecast tax policy. New England Economic Review, September/October, 29-48.

Frank, Murray, and Ravi Jagannathan, 1998, Why do stock prices drop by less than the value of the dividend? Evidence from a country without taxes, Journal of Financial Economics 47, 161-188.

Givoly, Dan, Carla Hahn, Aharon Ofer, and Oded Sarig, 1992, Taxes and capital structure: Evidence from firms' response to the tax reform act of 1986, Review of Financial Studies 5, 331-355. 
Gordon, Roger H., 1982, Interest rates, inflations, and corporate policy, Brookings Papers on Economic Activity 2: 461-488.

Gordon, Roger H., and Jeffrey K. MacKie-Mason, 1990, Effects of the Tax Reform Act of 1986 on corporate financial policy and organizational form, in J. Slemrod, ed., Do Taxes Matter? (MIT Press, Cambridge), 91-131.

Gordon, Roger H., and Jeffrey K. MacKie-Mason, 1994, Tax distortions and the choice of organizational form, Journal of Public Economics 55, 279-306.

Gordon, Roger H., and Jeffrey K. MacKie-Mason, 1997, How much do taxes discourage incorporation?, Journal of Finance 52, 477-505.

Gordon, Roger H., and David F. Bradford, 1980, Taxation and the stock market valuation of capital gains and dividends, Journal of Public Economics 14, 109-136.

Graham, John, 1996a, Debt and the marginal tax rate, Journal of Financial Economics 41, 41-73.

Graham, John, 1996b, Proxies for the corporate marginal tax rate, Journal of Financial Economics 42, 187-221.

Graham, John, 1999, How big are the tax benefits of debt? Should they be bigger? Duke University working paper.

Graham, John, and Michael Lemmon, 1998, Measuring corporate tax rates and tax incentives: A new approach, Journal of Applied Corporate Finance 11, 8-19.

Graham, John, Michael Lemmon, and James Schallheim, 1998, Debt, leases, taxes, and the endogeneity of corporate tax status, Journal of Finance 53, 131-162.

Green, Richard, 1993, A simple model of the taxable and tax-exempt yield curves, Review of Financial Studies 6, 233264. 
Green, Richard, and Kristian Rydqvist, 1999, "Ex-day behavior with dividend preference and limitations to short-term arbitrage: The case of Swedish lottery bonds," Journal of Financial Economics forthcoming.

Hansen, Lars, 1982, Large sample properties of generalized method of moments estimators, Econometrica 50, 10291054.

Jensen, Michael, 1986, Agency costs of free cash flow, corporate financing, and takeovers, American Economic Review $76,323-329$.

Lewellen, Wilbur, Kenneth Stanley, Ronald Lease, and Gary Schlarbaum, 1978, Some direct evidence on the dividend clientele hypothesis, Journal of Finance 33, 1385-1399.

Lindenberg, Eric, and Stephen Ross, 1981, Tobin's q ratio and industrial organization, Journal of Business 54, 181191.

MacKie-Mason, Jeffrey, 1990, Do taxes affect corporate financing decisions?, Journal of Finance 45, 1471-1493.

Mankiw, Gregory, and James Poterba, 1996, Stock-market yields and the pricing of municipal bonds, Harvard University Working Paper.

Michaely, Roni, 1991, Ex-dividend day stock price behavior: The case of the 1986 Tax Reform Act, Journal of Finance $46,845-59$.

Miller, Merton, 1977, Debt and taxes, Journal of Finance 32, 261-275.

Myers, Stewart, 1977, Determinants of corporate borrowing, Journal of Financial Economics 3, 799-819.

Myers, Stewart, 1984, The capital structure puzzle, Journal of Finance 39, 572-592.

Myers, Stewart, 1993, Still searching for the optimal capital structure, Journal of Applied Corporate Finance 6, 4-14. 
Myers, Stewart, and Nicholas Majluf, 1984, Corporate financing and investment decisions when firms have information that investors do not have, Journal of Financial Economics 13, 187-221.

Parzen, Emmanuel, 1957, On consistent estimates of the spectrum of a stationary time series, Annals of Mathematical Statistics 28, 329-348.

Poterba, James, 1989, Tax reform and the market for tax-exempt debt, Regional Science and Urban Economics, 537562.

Poterba, James, 1997, The rate of return to corporate capital and factor shares: New estimates using revised National Income Accounts and capital stock data, NBER working paper number 6263.

Rajan, Raghuram G., and Luigi Zingales, What do we know about capital structure choice? Some evidence from international data, Journal of Finance 50, 1421-1460.

Scholes, Myron, and Mark Wolfson, 1992, Taxes and Business Strategy: A Planning Approach, Prentice-Hall, Englewood Cliffs, N.J.

Scholz, John, 1992, A direct examination of the dividend clientele hypothesis, Journal of Public Economics 49, 26185.

Shum, Pauline, 1996, Taxes and corporate debt policy in Canada: An empirical investigation, Canadian Journal of Economics 29, 556-572.

Schulman, Craig, Deborah Thomas, Keith Sellers, and Duane Kennedy, 1996, Effects of tax integration and capital gains tax on corporate leverage, National Tax Journal 49, 31-54.

Scott, James H., 1976, A theory of optimal capital structure, Bell Journal of Economics 7, 33-54.

Shevlin, Terry, 1987, Taxes and off-balance sheet financing: Research and development limited partnerships, The 
Accounting Review 62, 480-509.

Shevlin, Terry, 1990, Estimating corporate marginal tax rates with asymmetric tax treatment of gains and losses, The Journal of the American Taxation Association 12, 51-67.

Trczinka, Charles, 1982, The pricing of tax-exempt bonds and the Miller hypothesis, Journal of Finance 37, 907-923.

Trezevant, Robert, 1992, Debt financing and tax status - Tests of the substitution effect and the tax exhaustion hypothesis using firms responses to the Economic Recovery Tax Act of 1981, Journal of Finance 47, 1557-1568.

White, Halbert, 1980, A heteroscedastic consistent covariance matrix and a direct test for heteroscedasticity, Econometrica 48, 817-838.

Zechner, Josef, 1990, Tax clienteles and optimal capital structure under uncertainty, Journal of Business 63, 465-491.

Zodrow, George, 1991, On the "Traditional" and "New" views of dividend taxation, National Tax Journal 44, 497-509. 
Table 1

Panel A: Summary statistics. Based on 65,429 observations over the years 1980-1994.

\begin{tabular}{lccccc} 
& Mean & Std. Dev. & Median & Minimum & Maximum \\
\hline BEN $_{\text {it }}{ }^{\mathrm{a}}$ & 0.040 & 0.146 & 0.088 & -0.427 & 0.302 \\
Debt-to-value $^{\mathrm{b}}$ & 0.213 & 0.186 & 0.177 & 0.000 & 0.988 \\
Z-score $^{\mathrm{c}}$ & 0.321 & 82.72 & 2.000 & -12520 & 2859 \\
ECOST $^{\mathrm{d}}$ & 3.307 & 132.4 & 0.033 & 0.000 & 21000 \\
NODIV $^{\mathrm{e}}$ & 0.589 & 0.492 & 1.000 & 0.000 & 1.000 \\
OENEG $^{\mathrm{f}}$ & 0.053 & 0.224 & 0.000 & 0.000 & 1.000 \\
q-ratio $^{\mathrm{g}}$ & 1.682 & 58.74 & 0.513 & -0.915 & 11648 \\
PPE-to-assets $^{\mathrm{h}}$ & 0.353 & 0.243 & 0.297 & 0.000 & 1.238 \\
Ln(real sales) & -0.461 & 2.489 & -0.373 & -11.99 & 7.606 \\
Op Income-to-assets $^{\mathrm{j}}$ & 0.025 & 1.963 & 0.113 & -218 & 10.4 \\
\hline
\end{tabular}

Panel B: Pearson correlations appear above the diagonal. Spearman rank correlations appear below the diagonal.

\begin{tabular}{lcccccccccc}
\hline & $B E N_{i t}$ & $\begin{array}{c}\text { Debt-to- } \\
\text { value }\end{array}$ & Z-score & ECOST & NODIV & OENEG & q-ratio & $\begin{array}{r}\text { PPE-to- } \\
\text { assets }\end{array}$ & $\begin{array}{r}\text { Ln(real } \\
\text { Sales) }\end{array}$ & $\begin{array}{c}\text { Op. Income } \\
\text { to assets }\end{array}$ \\
\hline$B E N_{i t}$ & & 0.063 & 0.049 & -0.039 & -0.559 & -0.270 & -0.032 & 0.129 & 0.605 & 0.110 \\
Debt-to-value & 0.077 & & $0.008^{\dagger}$ & -0.015 & 0.032 & 0.186 & -0.021 & 0.278 & 0.149 & 0.017 \\
Z-Score & 0.436 & -0.184 & & -0.372 & -0.023 & -0.075 & -0.712 & $-0.009^{\dagger}$ & 0.024 & 0.840 \\
ECOST & -0.230 & -0.224 & -0.074 & & 0.020 & 0.068 & 0.104 & -0.005 & -0.022 & -0.335 \\
NODIV & -0.649 & -0.020 & -0.350 & 0.206 & & 0.178 & 0.013 & -0.205 & -0.569 & -0.056 \\
OENEG & -0.228 & 0.143 & -0.279 & 0.058 & 0.179 & & 0.046 & $-0.009^{\dagger}$ & -0.133 & -0.115 \\
q-ratio & -0.122 & -0.528 & -0.191 & 0.150 & 0.081 & 0.111 & & -0.013 & -0.019 & -0.726 \\
PPE-to-assets & 0.198 & 0.305 & -0.179 & -0.334 & -0.235 & -0.019 & 0.037 & & 0.158 & 0.025 \\
Ln(real sales) & 0.604 & 0.199 & 0.409 & -0.192 & -0.595 & -0.130 & -0.201 & 0.226 & & 0.173 \\
OIA & 0.520 & -0.118 & 0.634 & -0.156 & -0.394 & -0.206 & 0.122 & 0.149 & 0.430 & \\
\hline
\end{tabular}

${ }^{a}$ Simulated marginal tax rate based on earnings before interest and taxes, net of the personal tax penalty.

${ }^{\mathrm{b}}$ Long-term debt plus debt in current liabilities, the sum divided by the market value of the firm. The market value of the firm is book assets minus book equity plus market equity.

${ }^{\mathrm{c}}$ Modified Altman's (1968) Z-score.

${ }^{\mathrm{d}}$ The standard deviation of the first difference in taxable earnings divided by assets, the quotient times the sum of advertising, research and development expenses divided by sales.

${ }^{\mathrm{e}}$ A dummy variable equal to one if the firm does not pay dividends.

${ }^{\mathrm{f}}$ A dummy variable equal to one if the firm has negative owners equity.

${ }^{\mathrm{g}}$ Preferred stock plus market value of common equity plus net short-term liabilities, the sum divided by total assets.

${ }^{\mathrm{h}}$ Net property, plant, and equipment divided by total assets.

${ }^{\mathrm{i}}$ The natural log of real sales (where sales is deflated by the implicit price deflator), with sales expressed in millions of dollars.

${ }^{\mathrm{j}}$ Operating cash flow divided by total assets.

${ }^{+}$not statistically significant at a $1 \%$ level. 
Summary information about the tax variables. The before-financing marginal tax rate (MTR) is based on earnings before interest and tax. The afterfinancing MTR is based on income before tax but after interest. The personal tax penalty is measured as $\tau_{p}-\left(1-\tau_{c}\right) \tau_{e}$, where $\tau_{p}$ is the personal tax rate on interest income, $\tau_{\mathrm{c}}$ is the corporate tax rate, and $\tau_{\mathrm{e}}$ is the personal tax rate on equity income.

Panel A: Annual distributions for tax benefits. The values at the $25^{\text {th }}$ percentile, the median, and the $75^{\text {th }}$ percentile are shown.

\begin{tabular}{|c|c|c|c|c|c|c|c|c|c|c|c|c|}
\hline & \multicolumn{6}{|c|}{ Considering personal tax penalty } & \multicolumn{6}{|c|}{ Ignoring personal tax penalty } \\
\hline & \multicolumn{3}{|c|}{ Before-financing MTR } & \multicolumn{3}{|c|}{ After-financing MTR } & \multicolumn{3}{|c|}{ Before-financing MTR } & \multicolumn{3}{|c|}{ After-financing MTR } \\
\hline & $25^{\text {th }} \%$ & Median & $75^{\text {th }} \%$ & $25^{\text {th }} \%$ & Median & $75^{\text {th } \%}$ & $25^{\text {th }} \%$ & Median & $75^{\text {th }} \%$ & $25^{\text {th }} \%$ & Median & $75^{\text {th }} \%$ \\
\hline 1980 & 0.012 & 0.012 & 0.057 & -0.171 & 0.012 & 0.012 & 0.452 & 0.460 & 0.460 & 0.000 & 0.460 & 0.460 \\
\hline 1981 & 0.012 & 0.041 & 0.097 & -0.256 & 0.012 & 0.090 & 0.447 & 0.460 & 0.460 & 0.000 & 0.460 & 0.460 \\
\hline 1982 & 0.058 & 0.089 & 0.147 & -0.304 & 0.075 & 0.137 & 0.411 & 0.460 & 0.460 & 0.000 & 0.441 & 0.460 \\
\hline 1983 & 0.040 & 0.075 & 0.151 & -0.366 & 0.075 & 0.140 & 0.397 & 0.460 & 0.460 & 0.000 & 0.441 & 0.460 \\
\hline 1984 & 0.030 & 0.075 & 0.151 & -0.366 & 0.075 & 0.141 & 0.384 & 0.460 & 0.460 & 0.000 & 0.441 & 0.460 \\
\hline 1985 & -0.016 & 0.075 & 0.150 & -0.366 & 0.061 & 0.135 & 0.332 & 0.460 & 0.460 & 0.000 & 0.407 & 0.460 \\
\hline 1986 & -0.065 & 0.075 & 0.143 & -0.366 & 0.012 & 0.127 & 0.268 & 0.460 & 0.460 & 0.000 & 0.363 & 0.460 \\
\hline 1987 & -0.046 & 0.102 & 0.152 & -0.261 & 0.009 & 0.135 & 0.193 & 0.390 & 0.390 & 0.000 & 0.275 & 0.390 \\
\hline 1988 & -0.034 & 0.099 & 0.144 & -0.217 & 0.015 & 0.129 & 0.173 & 0.340 & 0.340 & 0.000 & 0.239 & 0.340 \\
\hline 1989 & -0.047 & 0.099 & 0.143 & -0.217 & 0.003 & 0.129 & 0.167 & 0.340 & 0.340 & 0.000 & 0.210 & 0.340 \\
\hline 1990 & -0.041 & 0.099 & 0.144 & -0.217 & 0.000 & 0.126 & 0.165 & 0.340 & 0.340 & 0.000 & 0.147 & 0.340 \\
\hline 1991 & -0.044 & 0.099 & 0.142 & -0.217 & -0.002 & 0.122 & 0.161 & 0.340 & 0.340 & 0.000 & 0.111 & 0.340 \\
\hline 1992 & -0.038 & 0.099 & 0.142 & -0.217 & 0.000 & 0.117 & 0.170 & 0.340 & 0.340 & 0.000 & 0.153 & 0.340 \\
\hline 1993 & -0.121 & 0.090 & 0.134 & -0.226 & 0.000 & 0.119 & 0.093 & 0.327 & 0.350 & 0.000 & 0.197 & 0.350 \\
\hline 1994 & -0.096 & 0.090 & 0.134 & -0.226 & 0.018 & 0.119 & 0.121 & 0.340 & 0.350 & 0.000 & 0.243 & 0.350 \\
\hline
\end{tabular}


Panel B: Mean values for various tax variables, by year.

\begin{tabular}{|c|c|c|c|c|c|c|c|}
\hline & \multirow[b]{2}{*}{ div. payout $(d)$} & \multirow[b]{2}{*}{$\tau_{\mathrm{e}}$} & \multirow[b]{2}{*}{$\tau_{\mathrm{p}}$} & \multicolumn{2}{|c|}{ Before-financing MTR } & \multicolumn{2}{|c|}{ After-financing MTR } \\
\hline & & & & $\tau_{\mathrm{c}}$ & $\tau_{c}-\left[\tau_{p}-\left(1-\tau_{c}\right) \tau_{e}\right]$ & $\tau_{\mathrm{c}}$ & $\tau_{c}-\left[\tau_{p}-\left(1-\tau_{c}\right) \tau_{e}\right]$ \\
\hline 1980 & 0.183 & 0.125 & 0.474 & 0.415 & 0.014 & 0.324 & -0.066 \\
\hline 1981 & 0.242 & 0.150 & 0.474 & 0.413 & 0.024 & 0.319 & -0.059 \\
\hline 1982 & 0.240 & 0.128 & 0.407 & 0.397 & 0.065 & 0.286 & -0.035 \\
\hline 1983 & 0.245 & 0.131 & 0.407 & 0.388 & 0.057 & 0.282 & -0.038 \\
\hline 1984 & 0.240 & 0.128 & 0.407 & 0.380 & 0.048 & 0.275 & -0.047 \\
\hline 1985 & 0.233 & 0.126 & 0.407 & 0.366 & 0.034 & 0.255 & -0.066 \\
\hline 1986 & 0.223 & 0.122 & 0.407 & 0.356 & 0.023 & 0.241 & -0.081 \\
\hline 1987 & 0.215 & 0.126 & 0.331 & 0.296 & 0.051 & 0.198 & -0.037 \\
\hline 1988 & 0.205 & 0.114 & 0.287 & 0.259 & 0.054 & 0.172 & -0.024 \\
\hline 1989 & 0.206 & 0.115 & 0.287 & 0.258 & 0.054 & 0.169 & -0.027 \\
\hline 1990 & 0.212 & 0.116 & 0.287 & 0.258 & 0.055 & 0.164 & -0.030 \\
\hline 1991 & 0.210 & 0.116 & 0.287 & 0.257 & 0.054 & 0.160 & -0.034 \\
\hline 1992 & 0.209 & 0.115 & 0.287 & 0.258 & 0.054 & 0.165 & -0.029 \\
\hline 1993 & 0.207 & 0.117 & 0.296 & 0.236 & 0.027 & 0.175 & -0.029 \\
\hline 1994 & 0.199 & 0.115 & 0.296 & 0.249 & 0.036 & 0.183 & -0.023 \\
\hline 1980-1994 & 0.217 & 0.122 & 0.351 & 0.313 & 0.040 & 0.220 & -0.041 \\
\hline
\end{tabular}


Panel C: The relation between dividend-payout and the tax benefit of debt

Mean values for the before-financing corporate tax rate $\left(\tau_{c}\right)$, the net benefit of debt $\left(B E N=\tau_{c}-\left[\tau_{p}-\left(1-\tau_{c}\right) \tau_{e}\right]\right)$, and the personal tax penalty $\left(\tau_{p}-\left(1-\tau_{c}\right) \tau_{e}\right)$ grouped by dividend-payout $(d)$. Note that the personal tax penalty in inversely related to $d$.

\begin{tabular}{lcccc}
\hline Dividend-payout $(d)$ & Percent of sample firms & $\begin{array}{l}\text { Before-financing } \\
\text { corporate tax rate }\left(\tau_{c}\right)\end{array}$ & $\begin{array}{l}\text { Before-financing } \\
\text { net benefit of debt }(\mathrm{BEN})\end{array}$ & $\begin{array}{c}\text { Personal tax penalty } \\
\left(\tau_{\mathrm{c}}-\mathrm{BEN}\right)\end{array}$ \\
\hline$d=0.0$ & $56.8 \%$ & 0.267 & -0.034 & 0.301 \\
$0<d<0.25$ & 10.6 & 0.382 & 0.084 & 0.299 \\
$0.25 \leq d<0.50$ & 14.9 & 0.392 & 0.128 & 0.263 \\
$0.50 \leq d<1.0$ & 10.7 & 0.379 & 0.187 & 0.191 \\
$d=1.0$ & 7.0 & 0.326 & 0.211 & 0.115
\end{tabular}


Level-form capital structure regressions. Pooled cross-sectional time-series regressions are used to determine which factors affect the debt-to-value ratio. Column 3a (3f) results are based on a tax variable that is (is not) adjusted for personal taxes. The analyses in columns (3b) and (3c) add annual dummies to the regression in (3a), although the coefficients for the dummies are not shown because of space limitations. The analyses in columns (3d) and (3e) add annual dummies to the regression in (3a), and also control for firm fixed-effects. The tests of statistical significance for all the results are based on standard errors that are corrected for heteroskedasticity using White's (1980) correction, with the standard errors shown in parentheses.

Pooled cross-sectional time-series regressions, level of debt-to-value ${ }^{\mathrm{a}}$ as dependent variable

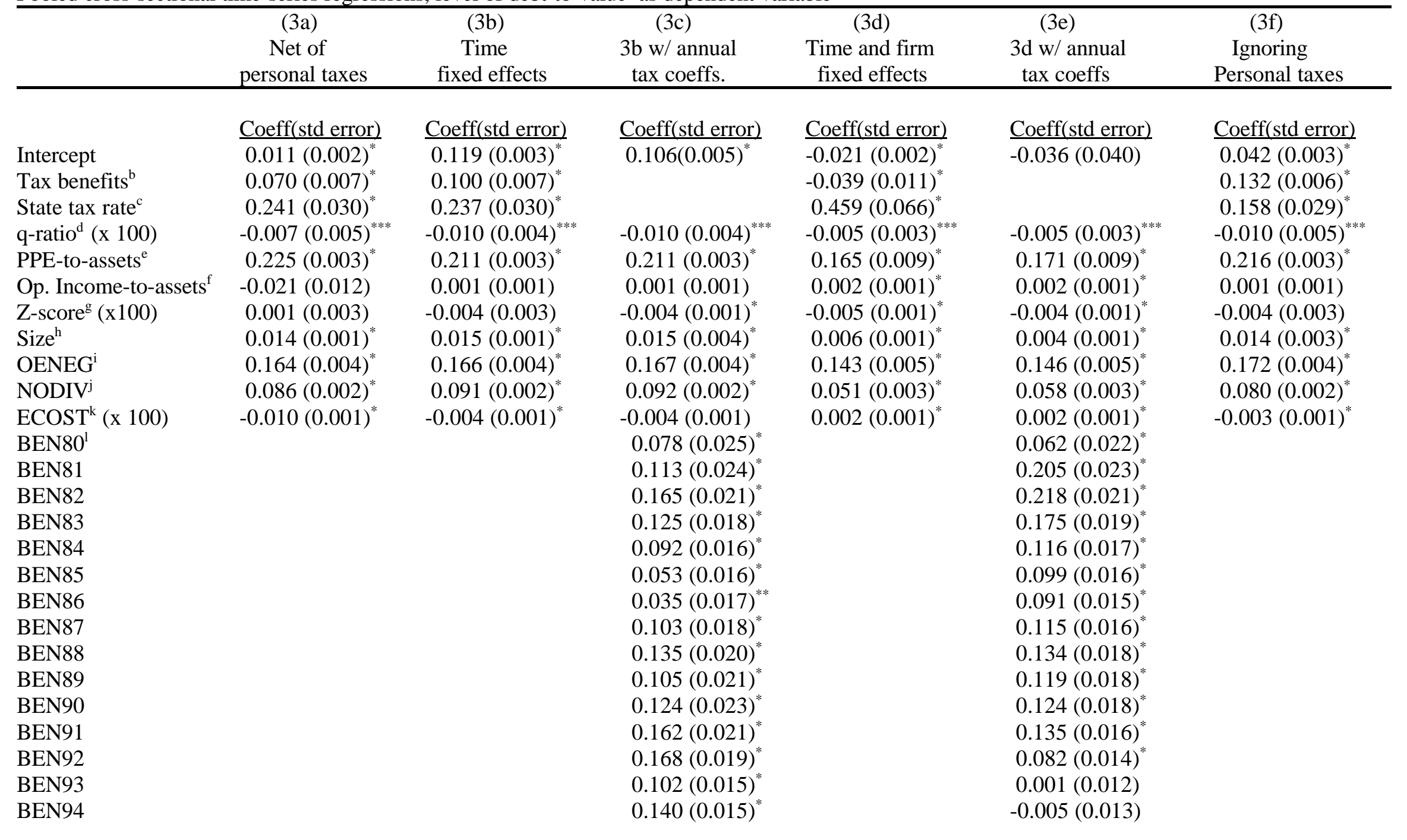




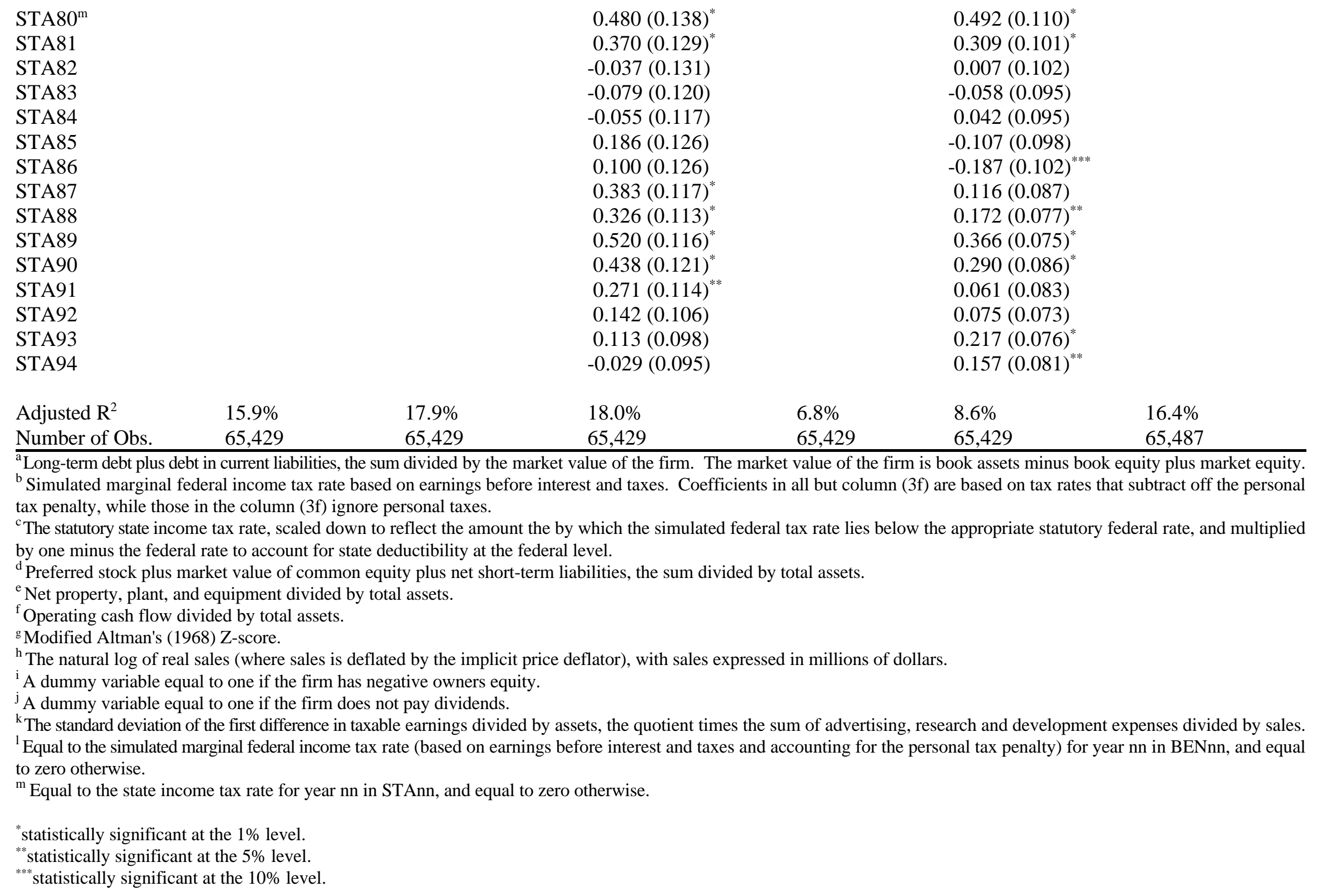


Alternative specifications using debt-to-value ${ }^{a}$ as dependent variable. Column (4a) is based on one observation per firm, where that observation is the firm-specific time-series average for each explanatory variable. All the other analyses are pooled cross-sectional time-series regressions. Instead of the simulated tax rates used in most of the paper, column (4b) uses the Poterba (1997) "weighted average marginal tax rates" found in his table A-1. Column $4 c$ (4d) repeats the regression from column (3a) of table 3 using firms with (without) credit ratings; these regressions use 1985-1994 data. The tests of statistical significance for all the results are based on standard errors that are corrected for heteroskedasticity, with the standard errors shown in parentheses.

\begin{tabular}{|c|c|c|c|c|}
\hline & $\begin{array}{c}\text { (4a) } \\
\text { One obs. per } \\
\text { firm }\end{array}$ & $\begin{array}{l}\quad(4 b) \\
\text { Poterba (1997) } \\
\text { ave. tax rates } \\
\end{array}$ & $\begin{array}{l}(4 \mathrm{c}) \\
\text { Firms with } \\
\text { credit ratings }\end{array}$ & $\begin{array}{l}\quad(4 d) \\
\text { Firms without } \\
\text { credit ratings }\end{array}$ \\
\hline $\begin{array}{l}\text { Intercept } \\
\text { Tax benefits }^{\mathrm{b}} \\
\text { State tax rate }^{\mathrm{c}} \\
\text { q-ratio }{ }^{\mathrm{d}} \text { ( 100) } \\
\text { PPE-to-assets }^{\mathrm{e}} \\
\text { Op. Income-to-assets } \\
\text { Z-score } \\
\text { Z }(\text { x 100) } \\
\text { Size }^{\mathrm{h}} \\
\text { OENEG }^{\mathrm{i}} \\
\text { NODIV }^{\mathrm{j}} \\
\text { ECOST }^{\mathrm{k}} \text { (x 100) }\end{array}$ & $\begin{array}{l}\text { Coeff(std error) } \\
0.116(0.006)^{*} \\
0.192(0.024)^{*} \\
0.182(0.095)^{* *} \\
-0.007(0.008) \\
0.213(0.009)^{*} \\
0.002(0.001)^{*} \\
-0.001(0.003) \\
0.002(0.001) \\
0.379(0.013)^{*} \\
0.050(0.006)^{*} \\
0.010(0.001)^{*}\end{array}$ & $\begin{array}{c}\text { Coeff(std error) } \\
0.072(0.002)^{*} \\
0.104(0.008)^{*} \\
0.190(0.031)^{*} \\
-0.010(0.004)^{* *} \\
0.218(0.003)^{*} \\
0.001(0.001) \\
-0.004(0.003) \\
0.015(0.001)^{*} \\
0.169(0.004)^{*} \\
0.080(0.002)^{*} \\
-0.004(0.001)^{*}\end{array}$ & $\begin{array}{c}\text { Coeff(std error) } \\
-0.321(0.007)^{*} \\
0.176(0.027)^{*} \\
-0.093(0.055)^{* * *} \\
-1.122(0.580)^{*} \\
0.131(0.006)^{*} \\
-0.264(0.032)^{*} \\
-0.020(0.050) \\
-0.019(0.001)^{*} \\
0.178(0.011)^{*} \\
0.078(0.005)^{*} \\
-0.017(0.005)^{*}\end{array}$ & $\begin{array}{c}\text { Coeff(std error) } \\
0.079(0.003)^{*} \\
0.066(0.011)^{*} \\
0.376(0.043)^{*} \\
-0.007(0.004)^{* * *} \\
0.197(0.005)^{*} \\
0.003(0.001)^{* *} \\
-0.007(0.004)^{* * *} \\
0.010(0.006)^{*} \\
0.157(0.005)^{*} \\
0.078(0.003)^{*} \\
-0.008(0.003)^{* *}\end{array}$ \\
\hline $\begin{array}{l}\text { Adjusted } R^{2} \\
\text { Number of Obs. }\end{array}$ & $\begin{array}{l}18.6 \% \\
10,100 \\
\end{array}$ & $\begin{array}{l}16.6 \% \\
65,429 \\
\end{array}$ & $\begin{array}{l}50.0 \% \\
7,557 \\
\end{array}$ & $\begin{array}{l}12.6 \% \\
33,107 \\
\end{array}$ \\
\hline $\begin{array}{l}{ }^{\mathrm{a}} \text { Long-term debt plus deb } \\
\text { book assets minus book e } \\
\mathrm{b} \text { Simulated marginal fede } \\
{ }^{\mathrm{c}} \text { The statutory state inco } \\
\text { appropriate statutory federa } \\
{ }^{\mathrm{d}} \text { Preferred stock plus mar } \\
{ }^{\mathrm{e}} \text { Net property, plant, and } \\
{ }^{\mathrm{f}} \text { Operating cash flow divi } \\
{ }^{\mathrm{g}} \text { Modified Altman's (1968 } \\
\mathrm{h}^{\mathrm{h}} \text { The natural log of real s. } \\
{ }^{\mathrm{i}} \text { A dummy variable equal } \\
{ }^{\mathrm{j}} \text { A dummy variable equal } \\
{ }^{\mathrm{k}} \text { The standard deviation } \\
\text { research and development }\end{array}$ & $\begin{array}{l}\text { al income tax rate bas } \\
\text { ne tax rate, scaled do } \\
\text { rate, and multiplied b } \\
\text { et value of common } \\
\text { quipment divided by } \\
\text { ed by total assets. } \\
\text { Z-score. } \\
\text { es (where sales is def } \\
\text { o one if the firm has } \\
\text { o one if the firm does } \\
\text { of the first difference } \\
\text { expenses divided by }\end{array}$ & $\begin{array}{l}\text { on earnings before ir } \\
\text { to reflect the amoun } \\
\text { ne minus the federal } \\
\text { iity plus net short-terr } \\
\text { al assets. } \\
\text { ed by the implicit pri } \\
\text { gative owners equity. } \\
\text { t pay dividends. } \\
\text { taxable earnings divi } \\
\text { es. }\end{array}$ & $\begin{array}{l}\text { st and taxes, net of th } \\
\text { which the simulated } \\
\text { to account for state d } \\
\text { bilities, the sum divid } \\
\text { eflator), with sales ex } \\
\text { by assets, the quotien }\end{array}$ & $\begin{array}{l}\text { e market value of the firm is } \\
\text { personal tax penalty. } \\
\text { ederal tax rate lies below the } \\
\text { uctibility at the federal level. } \\
\text { d by total assets. } \\
\text { essed in millions of dollars. } \\
\text { times the sum of advertising, }\end{array}$ \\
\hline
\end{tabular}


Table 5

Panel A: Annual regression for 1994, level of debt-to-value as dependent variable. Heteroskedastic-consistent standard errors in parentheses.

\begin{tabular}{lccc}
\hline & $\begin{array}{l}\text { Firm-specific } \\
\text { personal tax adjustment }\end{array}$ & Ignoring personal taxes & $\begin{array}{l}\text { Economy-wide } \\
\text { personal tax adjustment }\end{array}$ \\
\hline Intercept & $0.083(0.008)^{*}$ & $0.075(0.009)^{*}$ & $0.088(0.007)^{*}$ \\
Tax benefits $^{\mathrm{b}}$ & $0.090(0.023)^{*}$ & $0.063(0.024)^{*}$ & $0.071(0.027)^{*}$ \\
q-ratio $^{\mathrm{c}}$ & $-0.019(0.005)^{*}$ & $-0.019(0.006)^{*}$ & $-0.019(0.005)^{*}$ \\
PPE-to-assets $^{\mathrm{d}}$ & $0.200(0.009)^{*}$ & $0.201(0.009)^{*}$ & $0.201(0.009)^{*}$ \\
Op. Income-to-assets $^{\mathrm{e}}$ & $-0.038(0.017)^{* *}$ & $-0.037(0.017)^{* *}$ & $-0.037(0.017)^{*}$ \\
Z-score $^{\mathrm{f}}(\mathrm{x} \mathrm{10)}$ & $-0.003(0.003)$ & $-0.003(0.003)$ & $-0.001(0.001)$ \\
Size $^{\mathrm{g}}$ & $0.012(0.001)^{*}$ & $0.013(0.001)^{*}$ & $0.013(0.001)^{*}$ \\
OENEG $^{\mathrm{h}}$ & $0.175(0.014)^{*}$ & $0.174(0.001)^{*}$ & $0.174(0.014)^{*}$ \\
NODIV $^{\mathrm{i}}$ & $0.062(0.006)^{*}$ & $0.055(0.005)^{*}$ & $0.055(0.005)^{*}$ \\
ECOST $^{\mathrm{j}}$ (x 10) & $-0.006(0.003)^{* *}$ & $-0.006(0.003)^{* *}$ & $-0.006(0.003)^{* *}$ \\
& & & \\
Num. Obs. & 5120 & 5125 & 5125 \\
Adjusted-R & $25.5 \%$ & $25.3 \%$ & $25.3 \%$
\end{tabular}

Panel B: Tax coefficients for 15 annual regressions, 1980-1994, level of debt-to-value as dependent variable

\begin{tabular}{llcc}
\hline & $\begin{array}{l}\text { Firm-specific } \\
\text { personal tax adjustment }\end{array}$ & Ignoring personal taxes & $\begin{array}{c}\text { Economy-wide } \\
\text { personal tax adjustment }\end{array}$ \\
\hline Year & Tax coeff. estimates & Tax coeff. estimates & Tax coeff. estimates \\
1980 & $0.018(0.030)$ & $0.026(0.049)$ & $0.030(0.057)$ \\
1981 & $0.071(0.034)^{* *}$ & $-0.004(0.046)$ & $-0.005(0.052)$ \\
1982 & $0.213(0.029)^{*}$ & $0.169(0.031)^{*}$ & $0.194(0.036)^{*}$ \\
1983 & $0.140(0.025)^{*}$ & $0.109(0.026)^{*}$ & $0.125(0.029)^{*}$ \\
1984 & $0.120(0.027)^{*}$ & $0.114(0.030)^{*}$ & $0.131(0.011)^{*}$ \\
1985 & $0.083(0.025)^{*}$ & $0.060(0.026)^{* *}$ & $0.068(0.029)^{* *}$ \\
1986 & $0.034(0.024)$ & $0.014(0.025)$ & $0.016(0.029)^{*}$ \\
1987 & $0.158(0.028)^{*}$ & $0.132(0.028)^{*}$ & $0.151(0.032)^{*}$ \\
1988 & $0.174(0.034)^{*}$ & $0.155(0.036)^{*}$ & $0.176(0.042)^{*}$ \\
1989 & $0.151(0.031)^{*}$ & $0.121(0.031)^{*}$ & $0.137(0.035)^{*}$ \\
1990 & $0.187(0.035)^{*}$ & $0.155(0.036)^{*}$ & $0.175(0.040)^{*}$ \\
1991 & $0.248(0.031)^{*}$ & $0.186(0.030)^{*}$ & $0.212(0.034)^{*}$ \\
1992 & $0.146(0.032)^{*}$ & $0.103(0.033)^{*}$ & $0.117(0.037)^{*}$ \\
1993 & $0.071(0.020)^{*}$ & $0.035(0.020)^{* * *}$ & $0.039(0.023)^{* * *}$ \\
1994 & $0.090(0.023)^{*}$ & $0.063(0.024)^{*}$ & $0.071(0.027)^{*}$ \\
\hline
\end{tabular}

${ }^{a}$ Long-term debt plus debt in current liabilities, the sum divided by the market value of the firm. The market value of the firm is book assets minus book equity plus market equity.

${ }^{\mathrm{b}}$ Simulated marginal federal income tax rate based on earnings before interest and taxes. Coefficients in the left column are based on tax rates that subtract off a firm-specific personal tax penalty, while those in the middle column ignore personal taxes. Coefficients in the right column are based on tax rates that subtract off the mean annual personal tax penalty.

${ }^{c}$ Preferred stock plus market value of common equity plus net short-term liabilities, the sum divided by total assets.

${ }^{\mathrm{d}}$ Net property, plant, and equipment divided by total assets.

${ }^{\mathrm{e}}$ Operating cash flow divided by total assets.

${ }^{\mathrm{f}}$ Modified Altman's (1968) Z-score.

${ }^{\mathrm{g}}$ The natural $\log$ of real sales (where sales is deflated by the implicit price deflator), with sales expressed in millions of dollars.

${ }^{\mathrm{h}}$ A dummy variable equal to one if the firm has negative owners equity.

${ }^{\mathrm{i}}$ A dummy variable equal to one if the firm does not pay dividends.

${ }^{\mathrm{j}}$ The standard deviation of the first difference in taxable earnings divided by assets, the quotient times the sum of advertising, research and development expenses divided by sales.

"statistically significant at the $1 \%$ level.

*** statistically significant at the $5 \%$ level.

${ }^{* * *}$ statistically significant at the $10 \%$ level. 
Table 6

Estimation using the corporate tax rate and personal tax penalty as stand-alone explanatory variables. Heteroskedastic-consistent standard errors in parentheses.

Panel A: Annual regression for 1994, level of debt-to-value as dependent variable.

\begin{tabular}{lc}
\hline Intercept & $0.107(0.012)^{*}$ \\
Corporate tax benefits $^{\mathrm{b}}$ & $0.085(0.023)^{*}$ \\
Personal tax penalty $^{\mathrm{c}}$ & $-0.219(0.058)^{*}$ \\
q-ratio $^{\mathrm{d}}$ & $-0.019(0.005)^{*}$ \\
PPE-to-assets $^{\mathrm{e}}$ & $0.197(0.009)^{*}$ \\
Op. Income-to-assets & $\mathrm{f}$ \\
Z-score $^{\mathrm{g}}$ (x 10) & $-0.037(0.017)^{* *}$ \\
Size $^{\mathrm{h}}$ & $-0.003(0.003)^{*}$ \\
OENEG $^{\mathrm{i}}$ & $0.012(0.001)^{*}$ \\
NODIV $^{\mathrm{j}}$ & $0.174(0.014)^{*}$ \\
ECOST $^{\mathrm{k}}$ (x 10) & $0.071(0.006)^{*}$ \\
& $-0.006(0.003)^{*}$
\end{tabular}

Num. Obs. $\quad 5121$

Adjusted-R ${ }^{2} \quad 25.6 \%$

Panel B: Tax coefficients for 15 annual regressions, 1980-1994, level of debt-to-value as dependent variable

\begin{tabular}{lll}
\hline & Corporate tax benefit & Personal tax penalty \\
\hline$\underline{\text { Year }} 1980$ & coefficient estimates & $\frac{\text { coefficient estimates }}{-0.013(0.036)}$ \\
1981 & $0.025(0.050)$ & $-0.169(0.059)^{*}$ \\
1982 & $0.020(0.043)$ & $-0.246(0.057)^{*}$ \\
1983 & $0.200(0.031)^{*}$ & $-0.212(0.050)^{*}$ \\
1984 & $0.129(0.026)^{*}$ & $-0.099(0.049)^{*}$ \\
1985 & $0.123(0.030)^{*}$ & $-0.162(0.047)^{*}$ \\
1986 & $0.075(0.026)^{*}$ & $-0.087(0.047)^{*}$ \\
1987 & $0.023(0.026)$ & $-0.190(0.060)^{*}$ \\
1988 & $0.154(0.029)^{*}$ & $-0.191(0.071)^{*}$ \\
1989 & $0.175(0.036)^{*}$ & $-0.281(0.073)^{*}$ \\
1990 & $0.146(0.032)^{*}$ & $-0.287(0.081)^{*}$ \\
1991 & $0.179(0.037)^{*}$ & $-0.479(0.080)^{*}$ \\
1992 & $0.234(0.032)^{*}$ & $-0.331(0.068)^{*}$ \\
1993 & $0.133(0.033)^{*}$ & $-0.278(0.057)^{*}$ \\
1994 & $0.070(0.021)^{*}$ & $-0.219(0.058)^{*}$ \\
\hline
\end{tabular}

${ }^{a}$ Long-term debt plus debt in current liabilities, the sum divided by the market value of the firm. The market value of the firm is book assets minus book equity plus market equity.

${ }^{\mathrm{b}}$ Simulated marginal federal income tax rate based on earnings before interest and taxes, not adjusted for the personal tax penalty. ${ }^{c} \tau_{p}-\left(1-\tau_{c}\right) \tau_{e}$, with $\tau_{p}$ inferred from the difference between the muni and T-bill yield and $\tau_{\mathrm{e}}$ representing a weighted average between taxes paid on dividends and capital gains, with the weighting done with firm-specific dividend payout ratios.

${ }^{\mathrm{d}}$ Preferred stock plus market value of common equity plus net short-term liabilities, the sum divided by total assets.

${ }^{\mathrm{e}}$ Net property, plant, and equipment divided by total assets.

${ }^{\mathrm{f}}$ Operating cash flow divided by total assets.

${ }^{g}$ Modified Altman's (1968) Z-score.

${ }^{\mathrm{h}}$ The natural $\log$ of real sales (where sales is deflated by the implicit price deflator), with sales expressed in millions of dollars.

${ }^{\mathrm{i}}$ A dummy variable equal to one if the firm has negative owners equity.

${ }^{\mathrm{j}}$ A dummy variable equal to one if the firm does not pay dividends.

${ }^{\mathrm{k}}$ The standard deviation of the first difference in taxable earnings divided by assets, the quotient times the sum of advertising, research and development expenses divided by sales.

"statistically significant at the $1 \%$ level.

** statistically significant at the $5 \%$ level.

${ }^{* * *}$ statistically significant at the $10 \%$ level. 
Table 7

Capital structure regressions using the change in debt as dependent variable. The left (right) column of results are based on the change in the debt-to-value ratio (the net increase in long-term debt from the Sources and Uses of Funds statement divided by the market value of the firm). The tests of statistical significance are based on standard errors that are corrected for heteroskedasticity, with the standard errors shown in parentheses.

Panel A: Pooled cross-sectional time-series regressions.

\begin{tabular}{lcc}
\hline & Change in debt-to-value & Net source of funds from debt $\mathrm{b}^{\mathrm{b}}$ \\
\hline Intercept $^{\mathrm{a}}$ & $0.001(0.001)$ & $0.006(0.001)^{*}$ \\
Tax benefits $^{\mathrm{c}}$ & $0.027(0.003)^{*}$ & $0.054(0.003)^{*}$ \\
State tax rate $^{\mathrm{d}}$ & $-0.043(0.021)^{*}$ & $-0.081(0.020)^{*}$ \\
q-ratio $^{\mathrm{e}}$ (x 100) & $-0.010(0.003)^{* * *}$ & $-0.001(0.001)^{* *}$ \\
PPE-to-assets $^{\mathrm{f}}$ & $0.076(0.007)^{*}$ & $0.027(0.005)^{*}$ \\
Op. Income-to-assets $^{\mathrm{g}}(\mathrm{x} \mathrm{10)}$ & $-0.010(0.070)$ & $-0.005(0.002)^{* *}$ \\
Z-score $^{\mathrm{h}}$ (x 100) & $-0.003(0.003)^{*}$ & $-0.001(0.001)^{*}$ \\
Size $^{\mathrm{i}}$ & $0.006(0.001)^{*}$ & $0.003(0.001)^{*}$ \\
OENEG $^{\mathrm{j}}$ & $0.037(0.004)^{*}$ & $0.003(0.004)$ \\
NODIV $^{\mathrm{k}}$ & $0.009(0.003)^{*}$ & $-0.002(0.002)$ \\
ECOST $^{\mathrm{l}}$ (x 100) & $-0.002(0.001)^{* *}$ & $-0.001(0.001)^{* *}$ \\
& & \\
Num. Obs. & 53,069 & 53,069 \\
Adjusted-R & $1.8 \%$ & $1.2 \%$
\end{tabular}

Panel B: Tax coefficients for annual regressions, 1981-1994, incremental debt as dependent variable.

\begin{tabular}{|c|c|c|c|}
\hline & Dep. Var: & Change in debt-to-value & Net source of funds from debt \\
\hline Year & & $\underline{\text { Tax coeff. estimates }}$ & Tax coeff. estimates \\
\hline$\overline{1981}$ & & $0.109(0.026)^{*}$ & $0.067(0.011)^{*}$ \\
\hline 1982 & & $0.005(0.010)$ & $0.046(0.009)^{*}$ \\
\hline 1983 & & $0.040(0.008)^{*}$ & $0.021(0.007)^{*}$ \\
\hline 1984 & & $-0.029(0.008)^{* *}$ & $0.058(0.009)^{*}$ \\
\hline 1985 & & $-0.004(0.008)$ & $0.062(0.011)^{*}$ \\
\hline 1986 & & $0.010(0.008)$ & $0.051(0.008)^{*}$ \\
\hline 1987 & & $0.029(0.008)^{*}$ & $0.056(0.009)^{*}$ \\
\hline 1988 & & $0.027(0.010)^{*}$ & $0.061(0.009)^{*}$ \\
\hline 1989 & & $0.045(0.011)^{*}$ & $0.078(0.013)^{*}$ \\
\hline 1990 & & $0.026(0.011)^{*}$ & $0.065(0.010)^{*}$ \\
\hline 1991 & & $0.065(0.010)^{*}$ & $0.066(0.008)^{*}$ \\
\hline 1992 & & $0.029(0.010)^{*}$ & $0.052(0.010)^{*}$ \\
\hline 1993 & & $0.045(0.010)^{*}$ & $0.051(0.013)^{*}$ \\
\hline 1994 & & $0.032(0.009)^{*}$ & $0.038(0.007)^{*}$ \\
\hline
\end{tabular}

${ }^{a}$ Long-term debt plus debt in current liabilities, the sum divided by the market value of the firm. The market value of the firm is book assets minus book equity plus market equity.

${ }^{\mathrm{b}}$ Long-term debt issuance (Compustat data item 111) minus long-term debt reduction (Compustat data item 114).

${ }^{\mathrm{c}}$ Simulated marginal federal income tax rate based on earnings before interest and taxes and subtracting off the personal tax penalty.

${ }^{\mathrm{d}}$ The statutory state income tax rate, scaled down to reflect the amount the simulated federal tax rate lies below the appropriate statutory federal rate, and multiplied by one minus the federal rate to account for state deductibility at the federal level.

${ }^{\mathrm{e}}$ Preferred stock plus market value of common equity plus net short-term liabilities, the sum divided by total assets.

${ }^{\mathrm{f}}$ Net property, plant, and equipment divided by total assets.

${ }^{\mathrm{g}}$ Operating cash flow divided by total assets.

${ }^{\text {h }}$ Modified Altman's (1968) Z-score.

${ }^{\mathrm{i}}$ The natural $\log$ of real sales (where sales is deflated by the implicit price deflator), with sales expressed in millions of dollars.

${ }^{\mathrm{j}}$ A dummy variable equal to one if the firm has negative owners equity.

${ }^{\mathrm{k}}$ A dummy variable equal to one if the firm does not pay dividends.

${ }^{1}$ The standard deviation of the first difference in taxable earnings divided by assets, the quotient times the sum of advertising, research and development expenses divided by sales.

"statistically significant at the $1 \%$ level.

${ }^{* * *}$ statistically significant at the $5 \%$ level.

${ }^{* * *}$ statistically significant at the $10 \%$ level. 


\section{Table 8}

Economic significance of tax results. The regression coefficients from column (3a) of table 3 are used to estimate debt-to-value ratios for hypothetical "high tax rate" and "low tax rate" firms. The "typical" debt ratio shown in column (8a) is obtained by interacting the mean 1994 value for each explanatory variable by its respective coefficient and summing. The mean values for the federal (net of the personal tax penalty) and state tax variables are $3.6 \%$ and $3.3 \%$, respectively. The debt ratio in column $8 \mathrm{~b}(8 \mathrm{c})$ uses the mean tax rate plus (minus) one standard deviation for the tax variables; these values are $18.1 \%$ and $6 \%(-10.9 \%$ and $0.6 \%)$ for the federal and state tax variables, respectively. The debt ratio in column $8 \mathrm{~d}(8 \mathrm{e})$ uses the maximum (minimum) tax rates, respectively. The maximum values are $27.7 \%$ and $9.9 \%$ (and minimums are $-22.6 \%$ and $0 \%$ ) for the federal and state tax variables, respectively.

\section{Debt-to-value ratios based on}

(8a)

Mean 1994 tax

rates (8b)

Mean tax rates plus Mean tax rates one std. dev. minus one std. dev. (8d)

(8e) 


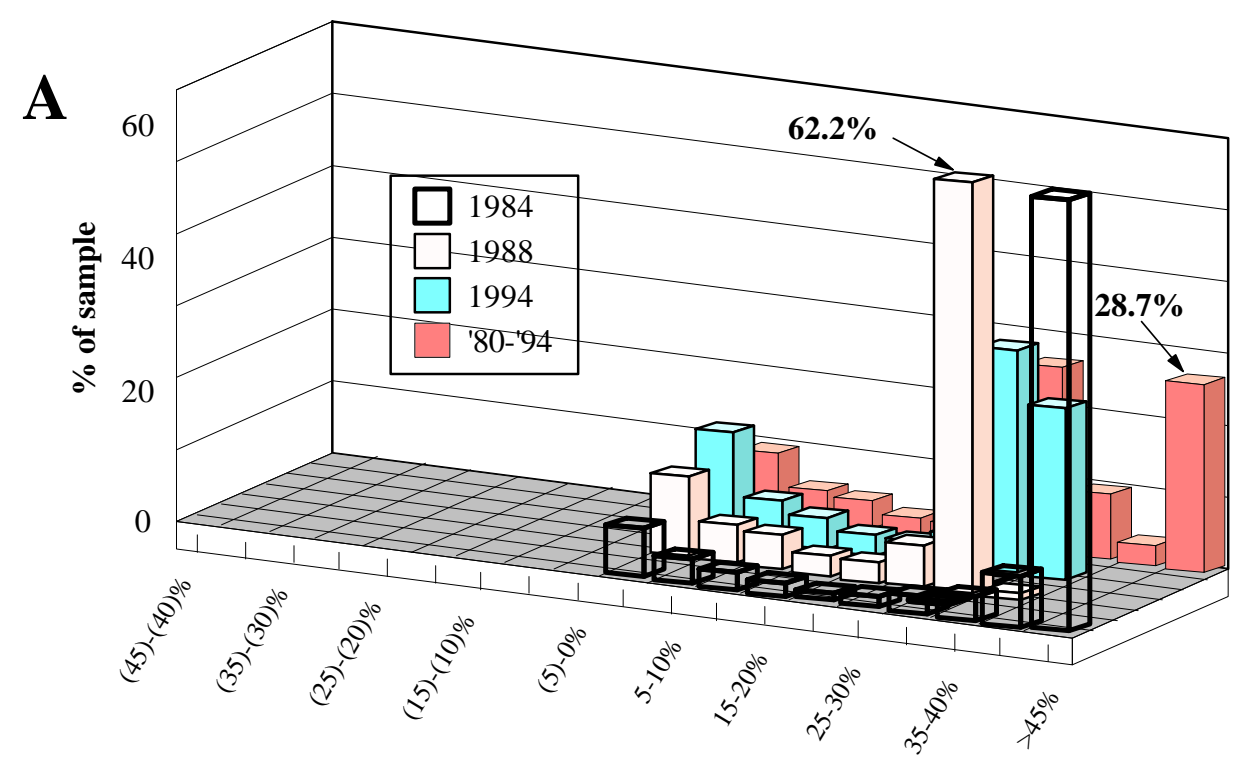

Before-financing tax rates

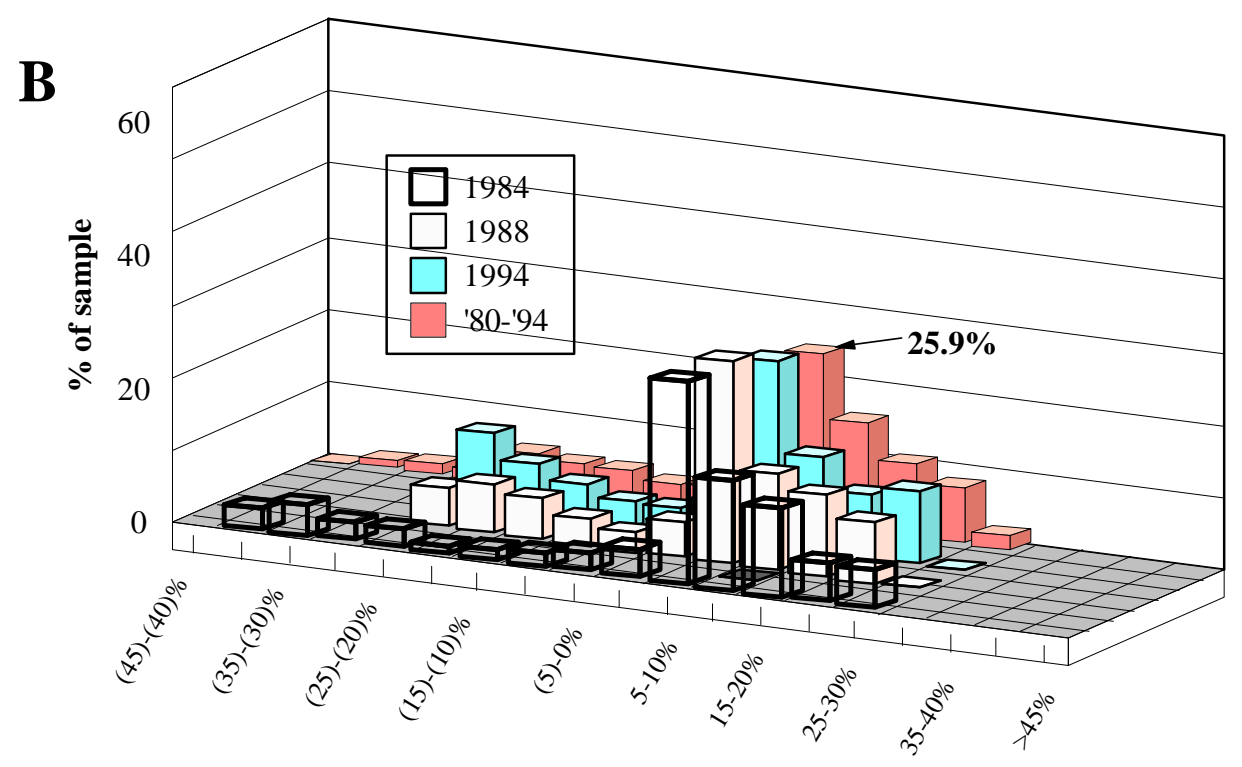

Before-financing tax rates, net of the personal tax penalty

Figure 1: Empirical distributions of corporate interest-deduction benefits.

The figure displays histograms for marginal federal income tax rates for Compustat firms for select years and aggregated over the period 1980-1994. The tax rates are calculated in a simulation procedure that accounts for the uncertainty about future taxable income, tax-loss and ITC carryforwards and carrybacks, and the AMT. The distributions in panel A are the raw marginal tax rates. The data in panel B adjust the tax rates to account for the personal tax penalty associated with interest income; therefore, they measure the net benefit of interest deductions. 


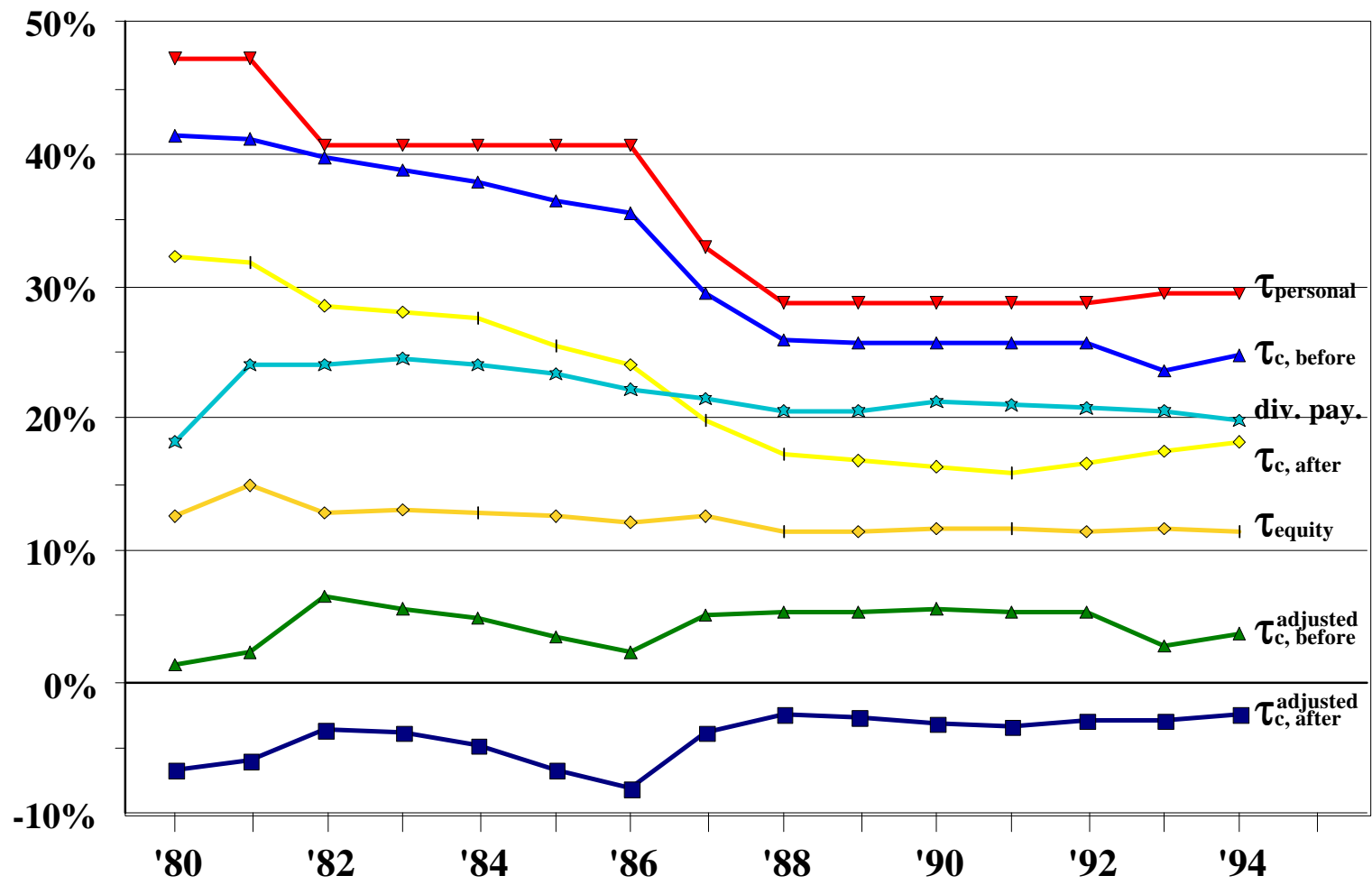

Figure 2: Mean values for various tax variables

The mean annual values for the tax variables are shown for each year 1980-1994. The definitions of the variables, by subscript, are as follows: "personal" is the personal tax rate on interest income, deduced from the difference between the yield on 1-year munis and the yield on 1-yr T-bills; "c, before" is the simulated corporate tax rate based on income before interest is deducted; "c, after" is the simulated corporate tax rate based on income after interest is deducted; and "equity" is the tax rate on equity income. The "adjusted" superscript indicates that the variable has been adjusted for the personal tax penalty. "div. pay." is the mean annual dividend-payout ratio. 